NBER WORKING PAPER SERIES

\title{
WHY DO BANKS PRACTICE REGULATORY ARBITRAGE? EVIDENCE FROM USAGE OF TRUST PREFERRED SECURITIES
}

\author{
Nicole M. Boyson \\ Rüdiger Fahlenbrach \\ René M. Stulz \\ Working Paper 19984 \\ http://www.nber.org/papers/w19984 \\ NATIONAL BUREAU OF ECONOMIC RESEARCH \\ 1050 Massachusetts Avenue \\ Cambridge, MA 02138 \\ March 2014
}

Boyson is from Northeastern University. Fahlenbrach is from Ecole Polytechnique Fédérale de Lausanne and is affiliated with the Swiss Finance Institute. Stulz is Everett D. Reese Chair of Banking and Monetary Economics, Fisher College of Business, Ohio State University, and is affiliated with NBER, ECGI and Wharton Financial Institutions Center. We thank Wolfgang Bühler, Jan Krahnen, Christian Leuz, Sascha Steffen, Elu von Thadden, and seminar participants at Bentley University, Bristol University, European School of Management and Technology, Goethe Universität Frankfurt, HEC Paris, Universität Mannheim, Universität St. Gallen, University of Oxford, and the University of Massachusetts at Amherst for helpful comments and suggestions. Brian Baugh and Andrei Goncalves provided valuable research assistance. René Stulz serves on the board of a bank that is affected by capital requirements and consults and provides expert testimony for financial institutions. The views expressed herein are those of the authors and do not necessarily reflect the views of the National Bureau of Economic Research.

NBER working papers are circulated for discussion and comment purposes. They have not been peerreviewed or been subject to the review by the NBER Board of Directors that accompanies official NBER publications.

(C) 2014 by Nicole M. Boyson, Rüdiger Fahlenbrach, and René M. Stulz. All rights reserved. Short sections of text, not to exceed two paragraphs, may be quoted without explicit permission provided that full credit, including $(\mathcal{C}$ notice, is given to the source. 
Why Do Banks Practice Regulatory Arbitrage? Evidence from Usage of Trust Preferred Securities Nicole M. Boyson, Rüdiger Fahlenbrach, and René M. Stulz

NBER Working Paper No. 19984

March 2014

JEL No. G01,G21

\begin{abstract}
$\underline{\text { ABSTRACT }}$
We propose a theory of regulatory arbitrage by banks and test it using trust preferred securities (TPS) issuance. From 1996 to 2007, U.S. banks in the aggregate increased their regulatory capital through issuance of TPS while their net issuance of common stock was negative due to repurchases. We assume that, in the absence of capital requirements, a bank has an optimal capital structure that depends on its business model. Capital requirements can impose constraints on bank decisions. If a bank's optimal capital structure also meets regulatory capital requirements with a sufficient buffer, the bank is unconstrained by these requirements. We expect that unconstrained banks will not issue TPS, that constrained banks will issue TPS and engage in other forms of regulatory arbitrage, and that banks with TPS will be riskier than other banks with the same amount of regulatory capital, and therefore, more adversely affected by the credit crisis. Our empirical evidence supports these predictions.
\end{abstract}

Nicole M. Boyson

Northeastern University

College of Business Administration

413C Hayden Hall

Boston, MA 02115-5000

n.boyson@neu.edu

Rüdiger Fahlenbrach

Ecole Polytechnique Fédérale de Lausanne (EPFL)

Quartier UNIL-Dorigny Bâtiment Extranef, \# 211

1015 Lausanne

Switzerland

ruediger.fahlenbrach@epfl.ch
René M. Stulz

The Ohio State University

Fisher College of Business

806A Fisher Hall

Columbus, OH 43210-1144

and NBER

stulz@cob.osu.edu 


\section{Introduction}

Among academics, regulators, and bankers, much attention is devoted to the appropriate level of bank capital (see Thakor (2013) for a review). Following the credit crisis, many have argued that regulatory capital requirements should be increased substantially. Banks can choose the composition of their capital within regulatory limits. The assets used in the computation of the main regulatory capital ratio are riskweighted and ignore a wide range of off-balance-sheet exposures. It is well known that many banks optimize their balance sheets and the composition of their capital to minimize the impact of capital requirements on their activities. This practice is often called regulatory arbitrage. While it is known that many banks engage in regulatory arbitrage, the existing literature does not explain why some banks do not. In this paper, we develop a theory of why banks engage in regulatory arbitrage and test the theory using banks' issuance of trust preferred securities (TPS) in the U.S. Our theory explains why some banks did not participate in regulatory arbitrage by issuing TPS.

In October 1996, the Federal Reserve Board authorized bank holding companies to include trust preferred securities (TPS) as Tier 1 regulatory capital up to a threshold level. As shown in Figure 1, U.S. bank holding companies raised regulatory capital in the aggregate through TPS and were net repurchasers of common stock from 1996 to 2007. TPS are a form of so-called hybrid capital. They are cumulative non-perpetual preferred securities issued by subsidiaries of bank holding companies whose sole asset is junior subordinated debt issued by the bank holding company. As with other debt, interest on TPS is taxdeductible to the bank holding company. Interest paid to the trust on the debt is used to pay quarterly dividends to TPS investors. Interest payments are deferrable for up to 20 quarters without triggering default. Using TPS instead of equity to meet regulatory capital requirements provides a bank with a weaker cushion in the event of an adverse shock, as TPS are effectively a mix of equity and debt. Hence, if two banks have exactly the same Tier 1 capital ratios, but one includes some TPS and the other includes only common equity, the all-equity bank is less likely to default given an adverse shock. Post-crisis regulatory changes eliminated the option for banks to increase regulatory capital through TPS issuance. 
We propose a simple theory of regulatory arbitrage. The theory is neoclassical in that it ignores agency problems. We assume that regulatory capital requirements impose a constraint on a bank's leverage and asset choices. Whether this constraint is binding depends crucially on the bank's optimal leverage in the absence of regulation. We assume that without capital requirements each bank has an optimal level of risk that depends on its business model. To achieve its target level of risk, the bank chooses an asset mix and a capital structure. We assume that the target level of risk can be represented by the bank's target probability of default. This assumption matches the economic capital approach used by large banks since these banks select their levels of economic capital to achieve a desired credit rating, which corresponds to a probability of default (see, for instance, Matten (2000)). In this simple world, a bank can have a target probability of default low enough that it is not constrained by regulatory capital requirements. By contrast, these regulatory requirements force some banks to be less risky than they would otherwise prefer. These constrained banks will practice regulatory arbitrage to come as close as possible to their target level of risk.

We assume that only two forms of capital are available to meet regulatory requirements: equity and TPS. We predict that an unconstrained bank will not issue TPS because TPS are effectively subordinated debt. Therefore, using TPS instead of equity would increase a bank's probability of default, which is suboptimal for an unconstrained bank already at its optimal level of risk. In contrast, for constrained banks, TPS create a valuable regulatory arbitrage opportunity. A constrained bank will issue TPS instead of equity because using TPS allows the bank to bring its probability of default closer to its target level, yet still satisfy regulatory capital requirements.

To test our theory, we have to determine whether or not a bank is constrained by capital requirements. We use two proxies for whether a bank is constrained. The first proxy is a bank's franchise value. An important finding in the banking literature is that banks with higher franchise value hold more capital because these banks have more to lose if they fail (see, for instance, Marcus (1983), Marcus (1984), Keeley (1990), and Demsetz, Saidenberg, and Strahan (1996)). High franchise value could arise from a number of factors, such as valuable relationships, a profitable deposit base, and so on. From our theory, 
we expect banks with high franchise values to be less constrained by capital requirements and to hold little or no TPS. We find strong support for this prediction. Our second proxy is a measure of how close a bank is to its regulatory capital threshold. In a world where raising capital quickly is costly, banks will hold a buffer stock of capital to cope with adverse shocks and to avoid the cost of raising capital. We consider a bank as constrained by regulation if its buffer stock of capital is low. ${ }^{1}$ Using the second proxy, we also find evidence consistent with our theory. Banks are more likely to use TPS if they are more constrained, i.e., if their excess regulatory capital levels are low.

If a bank is constrained by capital requirements, it can use TPS to alter the composition of its capital and increase the numerator of its Tier 1 capital ratio. ${ }^{2}$ However, it can also use its discretion to take actions that affect the denominator of the ratio, i.e., the risk-weighted assets. Under our theory, we would expect constrained banks to do both. Since the denominator of the capital ratio involves risk weights, banks cannot simply choose to increase asset risk. Rather, we expect constrained banks to choose to arbitrage these risk weights. Acharya, Schnabl, and Suarez (2013) examine such an arbitrage. They study how banks use asset-backed commercial paper (ABCP) conduits to reduce risk-weighted assets on their balance sheets and note that these conduits transfer the assets, but not the underlying risk, from bank balance sheets. As an additional test of our theory, we examine whether the same banks that use ABCP also use TPS, and find strong supportive evidence. Notably, of the 25 banks that have ABCP conduits, 24 also use TPS. A low Tier 1 ratio, one of our two proxies for capital constraints, predicts ABCP usage, and there is a positive and significant relation between TPS and ABCP usage in regression analyses.

With our theory, a constrained bank would quickly substitute equity with TPS upon passage of the new regulation to reduce the gap between its actual probability of default and the probability of default it

\footnotetext{
${ }^{1}$ We recognize that this approach is somewhat imprecise for two reasons. First, there are multiple capital requirements, so that a bank's buffer stock might differ substantially across measures. For instance, U.S. banks must meet a regulatory leverage ratio test where the denominator of the capital requirement formula is total assets rather than risk-weighted assets. A bank can have a large buffer with respect to the ratio that uses risk-weighted assets but a low buffer with respect to the leverage ratio. Second, a bank could choose to have a lower buffer stock simply because it has low risk. We control for systematic and idiosyncratic risk in our empirical analyses.

${ }^{2}$ Tier 1 capital for the period we study in this paper includes total shareholders' equity minus goodwill and other intangibles (except for mortgage-servicing rights) plus qualifying hybrid securities and non-controlling interests. Perpetual preferred stock and trust preferred securities were permitted up to a regulatory limit (approximately 15\% of a BHC's core capital for large banks and 25\% a BHC's core capital for small banks).
} 
would choose absent capital requirements. We find limited evidence that banks used TPS to repurchase common equity. One reason for this weak result is that bank regulators impose limits on the amount of common stock a bank may repurchase and on dividends it can pay. ${ }^{3}$ Given these constraints, it was more common for banks to use TPS as a source of funds when they had to increase their capital. For example, when they made acquisitions or experienced considerable internal growth that would have reduced their Tier 1 capital ratios, banks used TPS instead of equity to maintain their prior Tier 1 capital ratios.

With our theory, banks that meet capital requirements with TPS rather than equity should be riskier and hence more vulnerable to adverse shocks. We investigate our predictions and show that they hold. First, we find that banks with more TPS in Tier 1 capital have a lower distance to default during our sample period. Second, we find that banks with more TPS in Tier 1 capital are significantly more likely to receive funds from the Capital Purchase Program, the part of the Troubled Asset Relief Program through which the Treasury purchased newly issued preferred stock of banks. Third, banks with more TPS have a significantly lower return on assets during the crisis. Finally, we show that during the crisis, the equity of banks with more TPS performed substantially worse than the equity of other banks.

We contribute to three strands of the literature. First, we contribute to the literature on the determinants of bank capital. Second, we add to the literature on the impact of capital requirements on banks and on the determinants of regulatory arbitrage. Third, we contribute to the literature on TPS and other hybrid securities. A large body of research examines the determinants of bank capital (see Berlin (2011) and Thakor (2013) for reviews). A common finding in the empirical literature is that banks tend to hold significantly more capital than necessary to meet regulatory requirements. For example, Flannery and Rangan (2008) find that banks had capital levels that were $75 \%$ over the regulatory minima in the early 2000s. Berger et al. (2008) note that banks actively manage their capital ratios, set target levels above well-capitalized regulatory minima, and make rapid adjustments toward their targets. Our paper

\footnotetext{
${ }^{3}$ Regulators sometimes subject individual banks to additional constraints. For instance, a regulator might tell a bank that it cannot use TPS or that it must hold a larger capital buffer than required by regulation. While we cannot observe all the constraints regulators impose on banks, we provide some evidence that the observable constraint on stock repurchases and payouts prevented banks from using TPS as aggressively as they would have otherwise.
} 
adds to this literature by showing that banks manage not only the level, but also the composition, of their regulatory capital when capital requirements are binding.

Researchers have examined the impact of bank capital and capital regulation on risk shifting. For example, Hovakimian and Kane (2000) examine regulatory efforts to use capital requirements to control risk shifting by U.S. banks during 1985 to 1994 . We contribute to the risk-shifting literature by showing that constrained banks use TPS to get closer to their optimal leverage ratios, which in turn increases the probability of default. Other literature focuses on the relationship between bank capital and performance. Berger (1995) finds that banks with higher capital had better earnings in the 1980's. More recently, Mehran and Thakor (2011) also provide evidence that better capitalized banks perform better. DemirgucKunt, Detragiache, and Merrouche (2013) find that before the crisis bank capital was not related to performance, but that during the crisis, higher capital was positively related to stock performance. Beltratti and Stulz (2012) and Fahlenbrach, Prilmeier, and Stulz (2012) document a positive relationship between bank performance and Tier 1 capital during the recent crisis. Berger and Bouwman (2013) show a positive relationship between capital and market share during crises. All these papers focus either on Tier 1 capital or the ratio of book equity to assets, but none of them examine the influence of TPS. Our paper contributes to this literature by showing that, holding the amount of capital constant, banks with more TPS in their regulatory capital perform worse and are more likely to need government assistance during the crisis. Acharya, Gujral, and Shin (2009) show for a sample of 21 large international banks that the quality of bank capital deteriorated prior to the crisis.

There is also a literature documenting that banks engage in regulatory arbitrage. In fact, the very first working paper of the Basel Committee on Banking Supervision concluded: "banks have learnt how to exploit the broad brush nature of the requirements [...]. For some banks, this has probably started to undermine the meaningfulness of the requirements.” (Jackson (1999)). However, most of the literature on regulatory arbitrage has focused on showing the prevalence and types of regulatory arbitrage rather than 
modeling a bank's choice to engage in arbitrage. Finally, while there is a small literature on TPS, it only partially addresses the issues we focus on in this paper. ${ }^{4}$

The remainder of the paper is structured as follows. Section 2 presents our theory and derives testable hypotheses. Section 3 gives some background on TPS and Section 4 explains the data sources and offers summary statistics. Section 5 contains our main empirical analysis, and Section 6 concludes.

\section{A theory of regulatory arbitrage and predictions for the issuance of trust preferred securities}

Banks derive part of their value from providing low risk securities (see, e.g., DeAngelo and Stulz (2014) for a model and references to the literature). They also derive part of their value from loan relationships. Bank assets may become impaired when a bank becomes distressed or fails. As a result, a bank has to trade off the benefits of leverage against the potential costs of financial distress. The benefits of leverage include a greater ability of banks to supply low risk claims, potential tax benefits, and potential benefits from increasing the value of explicit and implicit guarantees, such as deposit insurance. The costs of financial distress differ across banks since they are business-model dependent, and can also depend on factors other than those already mentioned. For instance, a bank’s business model may involve selling long-dated derivatives. Counterparties to a bank for long-dated derivatives are unlikely to find such derivatives valuable if they are concerned about default risk. With this framework, each bank will choose its optimal level of risk, which corresponds to an expected probability of default (or a rating, if the bank is rated). The benefit of this simple approach is that it is consistent with how banks implement economic capital models. Using this approach allows us to derive implications for the use of regulatory arbitrage by banks and more directly about TPS issuance.

\footnotetext{
${ }^{4}$ Benston et al. (2003) examine 67 TPS issuances during 1996 and 1997. They find that the market responds favorably to TPS filings, and that issuers of TPS are larger and more sophisticated and have lower economic capital than non-issuers. Harvey, Collins and Wansley (2003) find that the issuance of TPS from 1996-2000 had a positive impact on bank stock prices, especially for firms that used TPS to retire common or preferred stock. Krishnan and Laux (2005) study trust preferred securities issued by both banks and other corporations, and find that the initial stock price reaction to the issuance of TPS is positive when issuers state a specific reason for issuance. Balasubramanian and Cyree (2010) argue that banks issue TPS to change their capital structure or improve capital ratios, but not for tax benefits. Finally, Kim and Stock (2012) show that the value of existing trust preferred securities increased when banks accepted TARP funding.
} 
We consider a very simple model of a bank using the intuition from Merton (1974). We assume that the bank manages its probability of default for date $\mathrm{T}$ and that it finances itself with equity and debt. The debt has no coupons and a face value $\mathrm{F}$ that is payable at date $\mathrm{T}$. In practice, banks often target their probability of default over a period of one year. We treat all debt the same. With these assumptions, we can use Merton (1974) for the value of the debt and for the probability of default.

More formally, following the Merton model, a bank's market value follows a geometric Brownian motion, $d V=\mu V d t+\sigma_{V} V d z$, where $V$ is the value of the bank, $\mu$ is the instantaneous expected rate of return, $\sigma_{V}^{2}$ is the instantaneous variance of the return on the firm per unit of time, and $d z$ is a standard Gauss-Wiener process.

With our assumptions, the bank’s probability of default is given by (see, e.g., Vassalou and Xing (2004)):

$$
P_{\text {default, } \mathrm{t}}=P\left(V_{t+T} \leq F_{t} \mid V_{t}\right)
$$

Since firm value follows a geometric Brownian motion, we have that

$$
\ln \left(V_{t+T}\right)=\ln \left(V_{t}\right)+\left(\mu-\frac{\sigma_{V}^{2}}{2}\right) T+\sigma_{V} \sqrt{T} \varepsilon_{t+T}
$$

where $\varepsilon_{t+T} \sim N(0,1)$. Hence, we can replace $V_{t+T}$ in equation (1) with equation (2):

$$
\begin{aligned}
P_{\text {default } \mathrm{t}} & =P\left(\ln \left(V_{t}\right)+\left(\mu-\frac{\sigma_{V}^{2}}{2}\right) T+\sigma_{V} \sqrt{T} \varepsilon_{t+T} \leq \ln \left(F_{t}\right)\right) \\
& =P\left(\varepsilon_{t+T} \leq-\frac{\ln \left(\frac{V_{t}}{F_{t}}\right)+\left(\mu-\frac{\sigma_{V}^{2}}{2}\right) T}{\sigma_{V} \sqrt{T}}\right)
\end{aligned}
$$

We can define the distance to default as $D D_{t}=\frac{\ln \left(\frac{V_{t}}{F_{t}}\right)+\left(\mu-\frac{\sigma_{V}^{2}}{2}\right) T}{\sigma_{V} \sqrt{T}}$. Because $\varepsilon_{t+T} \sim N(0,1)$, we have:

$$
\begin{aligned}
P_{\text {default, } \mathrm{t}} & =N\left(-\frac{\ln \left(\frac{V_{t}}{F_{t}}\right)+\left(\mu-\frac{\sigma_{V}^{2}}{2}\right) T}{\sigma_{V} \sqrt{T}}\right) \\
& =N(-D D)
\end{aligned}
$$


Assuming that $\mathrm{V}_{\mathrm{t}}$ and the distribution of the return on the bank's assets do not depend on $\mathrm{F}$, which is the standard assumption in applications of Merton (1974), the probability of default is increasing in the bank's leverage ratio and is increasing in the instantaneous variance of its return. In the model, the bank can decrease its probability of default by replacing debt with equity since doing so decreases $\mathrm{F}$ without changing anything else.

In the following analysis, we focus on a bank’s ability to select its debt and the volatility of the return of its assets. If investors are not risk neutral, the bank can also affect the expected return on its assets by changing the covariance of its return with the asset pricing kernel. We take this effect to be of secondorder for our analysis, so that we effectively assume risk neutrality. Since the bank chooses F and the volatility of the return of its assets, its probability of default is endogenously determined subject to constraints. $^{5}$

A bank may voluntarily choose a low probability of default. Gorton and Winton (2000) provide a model in which a bank chooses lower leverage to protect its charter value, which in their model comes from the value of the bank’s corporate borrowing relationships. In DeAngelo and Stulz (2014), a bank’s charter value comes from its ability to supply liquid claims, such as deposits. If a bank has valuable relationships with borrowers and depositors that would be lost in bankruptcy, it has incentives to keep its risk low. Demsetz, Saidenberg, and Strahan (1996) refer to such banks as having high franchise value. By contrast, a bank with less valuable relationships will find it optimal to take more risks if risk enables business growth. We adopt this perspective and view the relation between the value of a bank's assets and its probability of default as concave and bank specific, so that there is a different probability of default that maximizes each bank's value. Consistent with our perspective, financial institutions in practice typically target credit ratings and endeavor to achieve and maintain those ratings when they have a credit rating.

\footnotetext{
${ }^{5}$ Obvious constraints for banks are that regulations limit a bank's ability to increase the risk of its assets and that capital requirements limit a bank's leverage.
} 
Figure 2 shows the value of a bank, $\mathrm{V}$, as a concave function of the probability of default $\mathrm{p}$ in the absence of regulation for a high franchise value (HFV) bank and a low franchise value (LFV) bank. The probability of default that maximizes the value of the bank is $\mathrm{p}^{*}$. We define a bank's franchise value as the value that would be lost if the bank becomes distressed. A bank with high franchise value will have a low $\mathrm{p}^{*}, \mathrm{p}_{\mathrm{HFV}}^{*}$, and a bank with low franchise value will have a higher $\mathrm{p}^{*}, \mathrm{p}_{\mathrm{LFV}}^{*}$. Figure 2 displays the value of these two banks as a function of their $\mathrm{p}^{*}$.

We now analyze how these two banks are affected by the introduction of a regulator whose capital requirements imply that the bank's probability of default cannot exceed $\mathrm{p}^{\mathrm{R}}{ }^{6}$ Generally, banks want to hold a buffer of capital so that they will still meet regulatory requirements following an earnings shock. If a bank meets its regulatory capital requirements with an appropriate buffer when it chooses its probability of default $\mathrm{p}^{*}$, the capital requirements implied by $\mathrm{p}^{\mathrm{R}}$ do not affect the decisions of that bank, since the bank would choose the same probability of default absent these requirements. In Figure 2, this is true for the high franchise value bank. The low franchise value bank, in contrast, would choose a probability of default $\mathrm{p}^{*}>\mathrm{p}^{\mathrm{R}}$. Figure 2 shows that, in this case, the value of the bank is lower under capital constraints than if it were unrestricted in setting its capital structure.

Suppose now the regulator relaxes the rules for capital requirements by allowing banks to engage in regulatory arbitrage. Effectively, these weaker requirements imply an increase in the maximum probability of default a bank can choose. In Figure 2, this corresponds to a shift of $\mathrm{p}^{\mathrm{R}}$ to the right to $\mathrm{p}^{\mathrm{R}}$. Trust-preferred securities are one form of regulatory arbitrage. Because trust preferred securities are hybrids between debt and equity, allowing trust preferred securities in Tier 1 capital moves the regulatorimplied upper bound for the probability of default to the right. ${ }^{7}$ Figure 2 shows that the shift of $\mathrm{p}^{\mathrm{R}}$ to the

\footnotetext{
${ }^{6}$ We recognize that this is a highly simplistic view of capital requirements since banks can meet capital requirements with different choices of liability and asset structures. Nevertheless, our approach clarifies when a bank will find it valuable to practice regulatory arbitrage.

${ }^{7}$ Emanuel (1983) shows that the relation between the value of preferred stock and firm value is similar to the relation between the value of debt and firm value since the value of both instruments is a concave function of firm value. In contrast, the relation between the value of common stock and firm value is convex. Preferred stock is riskier than debt that ranks ahead of it in terms of bankruptcy priority, so that it is best viewed as a portfolio of debt and equity. Trust preferred securities are a type of preferred stock. Consequently, a bank that replaces equity with
} 
right to $\mathrm{p}^{\mathrm{R}}$ does not affect the value of the high franchise value bank. Note also that the tax advantage of the trust preferred securities is not relevant for this bank. This bank could achieve the same tax advantage by issuing debt - which would be cheaper - because it does not need to use trust preferred securities to meet capital requirements. It is also clear from Figure 2 that the introduction of TPS is useful for the low franchise value bank whose optimal probability of default $\mathrm{p}_{\mathrm{LFV}}^{*}$ is higher than $\mathrm{p}^{\mathrm{R}}$. The low franchise value bank in Figure 2 can increase its value by substituting TPS for equity in meeting its capital requirement until it reaches the threshold $\mathrm{p}^{\mathrm{R}}$. In other words, the bank benefits from regulatory arbitrage. Because the probability of default is inversely related to the ratio of equity to value, regulatory arbitrage allows a bank to meet its regulatory capital requirement with less equity. Of course, a financial institution will have access to multiple sources of regulatory arbitrage and will use all of them as long as capital requirements force it to have a lower probability of default than it would choose on its own.

To summarize, we derive the following testable hypotheses from our discussion:

H1: Banks that are constrained by capital regulation will issue TPS to increase their probability of default so that it is closer to its optimal level.

H2: Banks that are constrained by capital regulation will use both TPS and other types of regulatory arbitrages to increase their probability of default.

H3: Banks that are constrained by capital regulation will use TPS to be riskier than they otherwise could be, and will therefore have a shorter distance to default.

H4: Because banks with more TPS have a higher probability of default, their common stock will suffer more from adverse shocks.

TPS reduces its common equity and increases its long-term debt. From this perspective, keeping all else constant, replacing equity with trust preferred increases the probability that the bank will default. 


\section{Background on Trust Preferred Securities}

\section{A. Trust Preferred Securities and Tier 1 Capital}

Trust preferred securities (TPS) are cumulative non-perpetual preferred securities issued by subsidiaries (special purpose entities, or SPEs) of bank holding companies (BHCs) whose sole asset is junior subordinated debt issued by the BHC. The bank holding company typically purchases $100 \%$ of the common equity of the SPE (which typically represents about 3\% of the total assets of the trust). The SPE then issues preferred securities to investors. The SPE loans the offering proceeds of both the common and preferred securities to the bank holding company. In turn, the bank holding company issues deeply subordinated deferrable interest debentures to the SPE. The SPE is structured as a statutory business trust and is taxed as a partnership. Quarterly interest paid to the trust is used to pay dividends to holders of TPS. BHCs may defer this interest for up to 20 quarters without triggering default. If the BHC exceeds this deferral period, the note is considered in default and becomes immediately due and payable. Interest paid on the notes issued to the trust is tax-deductible for the BHC. Most TPS are callable after 5 or 10 years, and all TPS are mandatorily redeemable after 30 or 40 years.

This type of security has been used by non-bank corporations since 1993, and is also known as monthly-income preferred stock (MIPS) or quarterly-income preferred stock (QUIPS). ${ }^{8}$ The first TPS issue by a BHC did not occur until after October 21, 1996, when the Board of Governors of the Federal Reserve System (FRB) announced that bank holding companies may include trust preferred securities up to $25 \%$ of core capital for their highest quality (Tier 1 ) regulatory capital. ${ }^{9}$ Core capital is a grossed up version of Tier 1 capital that does not reflect deductions for disallowed intangible assets, goodwill, and disallowed deferred tax assets.

\footnotetext{
${ }^{8}$ These securities were frequently issued by corporations, with over $\$ 65$ billion issued by 300 corporations between 1993 and 1999 (Benston et al. (2003)). For more information, see Engel, Erickson, and Maydew (1999).

${ }^{9}$ Generally speaking, the calculation of regulatory capital begins with total shareholder's equity, subtracts disallowed items (such as goodwill and deferred tax assets) and adds permissible items that are not included in shareholder's equity (such as a minority interest in a consolidated subsidiary). See Appendix A for a detailed description of Tier 1 capital.
} 
Importantly, these securities would not qualify as Tier 1 capital if the BHC were to directly issue cumulative non-perpetual preferred stock. Therefore, the TPS structure facilitates regulatory arbitrage. While BHCs are permitted to include TPS in regulatory capital, their subsidiary depository institutions are not, with the Federal Deposit Insurance Corporation (FDIC) arguing that TPS do not provide sufficient capital support. Therefore, all TPS issuance is at the bank holding company level.

\section{B. Changes to the TPS market through time}

In 2000, Salomon Smith Barney issued the first TPS collateralized debt obligation, allowing small BHCs to issue TPS through a pooled structure. ${ }^{10}$ This market grew rapidly, with about $\$ 60$ billion issued by over 1,800 banks between 2000 and 2007 (Cordell, Hopkins, and Huang (2011)).

Until 2003, the SPE was consolidated at the BHC level and the trust preferred securities issued by the SPE were classified as a minority interest in the equity accounts of consolidated subsidiaries. However, FASB changed their accounting treatment in 2003. Under the new rules, the SPEs must be deconsolidated from their BHC sponsors' financial statements under GAAP. A BHC must reflect on its consolidated balance sheet the deeply subordinated note it issued to the deconsolidated SPE. Because the initial Tier 1 treatment of TPS hinged on the securities being classified as a minority interest, the new FASB rule caused uncertainty as to how the Federal Reserve would treat these instruments for regulatory capital purposes. This uncertainty was resolved on May 6, 2004 when the FRB proposed new regulations allowing TPS to maintain their Tier 1 status. ${ }^{11}$

Although interest payments made to the trust are deferrable, deferred payments must be recorded as a liability, which reduces equity capital at the BHC. During the financial crisis, a number of BHCs, mostly small and mid-sized, encountered severe financial difficulty and began deferring dividends on TPS. In addition, the TPS-CDO market shut down when the broader CDO market shut down, leading to severe illiquidity in the TPS-CDO market.

\footnotetext{
${ }^{10}$ French et al. (2010) provide a detailed description of the history of TPS.

${ }^{11}$ See 12 CFR part 225, App.A, II.A.1.b.
} 
The Dodd-Frank Act signed into law on July 21, 2010 made major changes to the TPS regulatory environment. The Collins amendment to Dodd-Frank states that TPS issued after May 19, 2010 (September 12, 2010 for BHCs with below \$15 billion in assets), are not eligible as Tier 1 capital, except for BHCs with below $\$ 15$ billion in assets. BHCs with over $\$ 15$ billion in assets must phase out TPS from Tier 1 over a three-year period beginning in January $2013 .{ }^{12}$ As a result, not a single BHC with assets over \$500 million issued TPS after September 12, 2010.

\section{Data}

Our data come from several sources. The core sample is an unbalanced panel of all publicly traded U.S. bank holding companies that report on form FR Y-9C, which is filed quarterly on a consolidated basis by all domestic bank holding companies with over $\$ 150$ million in assets (\$500 million after 2006). This data is from the Federal Reserve Bank of Chicago. Our dataset covers the period from 1996 to 2012, and includes 857 BHCs. Data on individual trust preferred securities are from SNL Financial, a private data provider that uses information from a variety of sources to create a proprietary database. We supplement the TPS data from SNL Financial using hand-collected data from forms 10-K, 10-Q, 8-K, and TPS prospectuses (for publicly traded TPS) found at the SEC's website. Some data on publicly traded TPS is from Quantum Online, a website that collects information about publicly traded preferred securities. Detailed data on mergers and acquisitions come from SNL Financial. Stock price data come from CRSP. Finally, data on BHC failures and delistings are hand-collected from the SEC’s website.

\section{A. TPS Summary Statistics}

We have data on 1,467 separate TPS issuances. Figure 3 shows the total amount of TPS, the total Tier 1 qualified TPS outstanding by quarter, and the proportion of BHCs that have issued TPS. The total

\footnotetext{
${ }^{12}$ These new requirements are generally consistent with, and in some cases more stringent than, the Basel III capital standards. Dodd-Frank also phases out cumulative perpetual preferred stock and mandatory convertible securities, whose usage has been much less extensive than TPS in the US (TPS made up 82\% of restricted Tier 1 capital as of December 2010.) Both Dodd-Frank and Basel III also propose other changes to regulatory capital requirements.
} 
amount of TPS outstanding (Tier 1 qualified TPS) for publicly-traded BHCs was just under \$20 (\$20) billion at the end of 1996 and rose to a peak of about \$140 (\$120) billion in early 2010. It is evident from the figure that banks did not initially issue more TPS than would count towards Tier 1 capital. Total TPS exceeds Tier 1 qualified TPS during the financial crisis not because BHCs issued more TPS, but because net losses during this period caused BHCs to reach the Fed-imposed TPS core capital threshold. The proportion of BHCs with TPS increased significantly over the sample period, rising from less than $10 \%$ to about $80 \%$ by the end of 2005 , where it remained steady until 2010 . This increase is partially caused by increased merger activity, which reduced the number of BHCs in the sample over time. The BHCs that leave the sample are less likely to have TPS, since across the entire sample of 857 BHCs, about $40 \%$ never issue TPS. After Dodd-Frank was enacted in the third quarter of 2010, qualified TPS dropped from $\$ 120$ billion to just under $\$ 100$ billion by the first quarter of 2012 . The more significant event was a Notice of Proposed Rulemaking (NOPR) on June 7, 2012, which reiterated the Dodd-Frank requirement that BHCs phase out their TPS in Tier 1 capital over a three year period beginning January 2013. Many BHCs treated the NOPR as a "qualifying event" that allowed them to redeem TPS prior to its call date. ${ }^{13}$ During the last three quarters of 2012, total qualified TPS dropped another $\$ 40$ billion, ending at just under $\$ 60$ billion at the end of 2012.

Figure 4 presents additional data regarding TPS. Panel A shows the average qualified TPS / Tier 1 ratio and the average total TPS / Tier 1 ratio, by quarter. Only BHCs with TPS during the quarter are included. This figure shows that BHCs with TPS typically issue substantial amounts, almost from the very start. In other words, banks use TPS to significantly change the composition of their capital, which is consistent with our hypotheses. Although the number of BHCs that issue TPS increases dramatically over this time period, the TPS / Tier 1 ratio remains fairly steady over time, averaging about 20\% through 2003, when it drops to about $18 \%$. The ratio then declines steadily, reaching a level of about $14 \%$ by the end of 2012 as banks adjust to regulatory changes.

\footnotetext{
${ }^{13}$ Most TPS include a provision allowing immediate call in the case of a qualifying "tax or regulatory event." A tax or regulatory event would be deemed to occur if, for example, TPS no longer qualified as Tier 1 capital or lost its tax-deductibility status.
} 
Panel B of Figure 4 shows a histogram of the outstanding TPS as a fraction of Tier 1 capital for our sample of bank holding companies (BHCs) between 1996 and 2007, again conditional on a bank having TPS issued and outstanding in the respective year. ${ }^{14}$ Panel B demonstrates that there is a wide crosssectional distribution of TPS / Tier 1 ratios; bank holding companies do typically not issue the maximum possible amount. The histogram suggests that banks choose an amount of TPS / Tier 1 that is optimal for them, which is consistent with our theory. Note that while there is some clustering of TPS / Tier 1 at the 0.25 threshold, there are many BHC-year observations with more than 25\% TPS in their Tier 1 capital. French et al. (2010) point out that this is not inconsistent with regulatory limits. The maximum amount of TPS allowable is based on TPS / core capital, not TPS / Tier 1 capital. Since core capital does not reflect deductions for disallowed intangible assets, goodwill, disallowed deferred tax assets and other deductions, TPS legally may comprise more than 25 percent of actual Tier 1 capital.

Table 1 Panel A provides detailed data at the TPS issuance level. The largest number of securities (209) was issued in 2003, with the highest dollar amount issued in 2007 (about \$36 billion). Panel A also details the method of issue, divided into four categories. First, banks can publicly list the TPS securities. Second, they can issue TPS in a traditional private placement. ${ }^{15}$ Third, banks can privately place their TPS under Rule 144A. ${ }^{16}$ Finally, banks can issue TPS through a TPS-CDO structure (pooled). The last column provides details on dividend deferrals as a result of BHCs deferring interest payments to the trusts. Most deferrals occur in 2009, with 43 banks deferring 146 TPS issues. A BHC may not defer interest to trusts holding TPS unless it also defers dividends on common and other preferred stock.

\footnotetext{
${ }^{14}$ The data underlying the histogram excludes 106 BHC-firm years for internationally active banks because a different regulatory upper limit for TPS / Tier 1 applies to them. Since there are so few observations, including them in the histogram will not significantly change the distribution. We only show the histogram from 1996 to 2007, because banks did not issue TPS during the crisis and starting redeeming them after regulatory changes in 2010.

${ }^{15}$ In a traditional private placement, BHCs issue these securities to an unlimited number of accredited investors. The placement is generally conducted on a best-efforts basis, and the securities are restricted from resale for at least a year (see Arena (2011) for details).

${ }^{16}$ The SEC introduced Rule 144A private placements in 1990. Unlike traditional private placements, Rule 144A placements may be traded among Qualified Institutional Buyers without a minimum holding period. Qualified Institutional Buyers include banks, savings and loans, and BHCs with audited net worth of at least \$25 million, insurance companies or pension plans with at least $\$ 100$ million in investible assets, brokers and dealers registered under the Exchange Act, and entities whose equity holders are all Qualified Institutional Buyers.
} 
Panel B provides data on bank-stated reasons for TPS issuance. We hand-collect these data from SEC filings and news releases for all TPS issuances. Consistent with our theory, banks rarely issue TPS to pay down debt (5\%), which would lower their probability of default. Rather, they use it to fund acquisitions or growth (22\%), thereby reducing the amount of common stock they must issue to meet capital requirements following an increase in their assets. In addition, they state they use TPS to improve regulatory capital $16 \%$ of the time. Panel C presents the average underwriting costs of common stock, preferred stock, long-term debt with different seniorities, and TPS. Cost data are available from 2000 forward. The underwriting cost is the difference between the price paid to the issuer and the price at which the shares are sold, as a percent of the price at which the shares are sold. Averages are taken by year, and then across years. Underwriting costs are significantly higher for common stock than for TPS, but lower for long-term debt, indicating that in addition to being a tax-deductible type of Tier 1 capital, TPS are also less expensive to issue than common stock.

\section{B. Bank Holding Company Data}

Table 2 presents summary statistics of annual data at the bank holding company level. There are 857 unique banks. Means and medians are calculated first by bank and then across banks, and are presented in two categories: banks that issued TPS at any time during the sample period (518 banks) and banks that did not (339 banks). ${ }^{17}$ Following Demsetz, Saidenberg, and Strahan (1996), we calculate franchise value as the sum of the market value of equity and the book value of liabilities, scaled by book value of assets minus goodwill.

Consistent with our theory that TPS issuers are constrained by capital requirements, both franchise value and Tier 1 ratio are significantly lower for TPS issuers than for non-issuers. Further, TPS issuers are larger, have higher risk-weighted assets, worse ROA, worse stock performance, higher betas, lower deposits, lower cash, more loans, and higher derivative usage. They are also more likely to repurchase

\footnotetext{
${ }^{17}$ Banks that acquire but never issue TPS (6 banks) are included in the "did not issue" category. Results do not change if we change the categorization of these banks.
} 
stock, and have higher internal and external growth than unconstrained banks. The results are consistent across means and medians.

\section{Empirical Analysis}

In this section, we investigate whether the data are consistent with the hypotheses we present in Section 2. The first hypothesis is that banks that issue TPS are constrained by regulatory capital requirements. We investigate a bank's first issuance decision for TPS and then relate the ratio of TPS to Tier 1 capital to our proxies for capital constraints. The second hypothesis is that constrained banks will also use other types of regulatory arbitrage, so we investigate whether banks that choose TPS also use ABCP. The third hypothesis is that constrained banks that use TPS are choosing to be riskier and, therefore, will have a shorter distance to default, which we test by examining the relationship between lagged TPS usage and a bank’s z score. Finally, we investigate how constrained banks with a higher probability of default are affected by an adverse shock - the credit crisis - by examining their likelihood of requiring TARP funding and by evaluating their operating and stock performance in the crisis.

\section{A. TPS Initial Issuance Decision}

We use a Cox proportional hazard model to examine the determinants of the decision by a BHC to issue TPS for the first time. The proportional hazard model relates the explanatory variables to the hazard of first-time TPS issuance during the next time interval. The model takes into account that not all BHCs issue TPS during the sample period. Because we model the time to first issuance, all subsequent issues are ignored. TPS that come on the balance sheet through an acquisition are not treated as issuances. Table 3 reports hazard ratios, which enable us to assess more easily the economic significance of the explanatory variables. A hazard ratio greater than 1 means that an increase in the value of the variable is associated with a greater likelihood of issuing TPS. The opposite is true if the ratio is less than 1 .

We predict that banks that are more constrained by capital requirements are more likely to issue TPS. The coefficients on our two proxies for financial constraints are statistically significant and have hazard 
ratios less than 1 in all five specifications. Further, these coefficients are economically significant in all specifications. The hazard ratio for franchise value is important for our theory since we predict that banks with higher franchise values are less likely to issue TPS. The value of 0.157 in specification (1) means that the expected probability of issuing TPS is about $84.3 \%$ lower when franchise value increases by 1 unit. Since the standard deviation of franchise value is 0.073 , this implies that for a one standard deviation increase in franchise value the likelihood of a bank issuing TPS goes down by 6\%. Similarly, the hazard ratio of 0.864 for the Tier 1 ratio (\%) in Column (3) implies that for a one percentage point increase in the Tier 1 ratio (\%), the probability of issuing TPS goes down by $14 \%$.

Specifications (1) through (5) indicate that other variables are associated with capital requirement constraints. Specifically, we would expect banks with strong asset growth, banks that engage in mergers, banks with poor earnings, and banks with riskier assets to be more constrained, and indeed, we show that these banks are more likely to issue TPS. We would expect banks with higher levels of cash relative to assets to have business models that benefit from relatively low risk, and we find supporting evidence that these banks are less likely to issue TPS. Although we have no prediction about the relation between derivatives trading and TPS issuance, we show that BHCs with high levels of trading derivatives are significantly more likely to issue TPS. To examine whether taxes affect the likelihood of issuing TPS, we use the state tax rate. The hazard ratio for the state tax rate is not significantly different from one.

Larger BHCs and BHCs with good prior period stock performance are more likely to issue TPS, which is inconsistent with the view that banks are constrained by capital requirements because of poor performance. Another indication that issuers are not poor performers, but rather are banks that choose to have low levels of capital, is that banks that repurchase stock are more likely to issue TPS.

In an untabulated analysis, we compare Tier 1 ratios for BHCs in the year prior to issue and in the year following issue. The average first-time issuer has a Tier 1 ratio of $11.3 \%$ in the year prior to issue and a remarkably similar Tier 1 ratio of $11.4 \%$ in the year following issue, despite issuing TPS of about $17 \%$ of the prior year's Tier 1 capital. Where does this extra capital go? Consistent with Table 3, BHCs use the extra capital to fund acquisitions and internal growth. The average asset growth for first time 
issuers is $25 \%$ of assets, or about $\$ 2.5$ billion. Had these banks not issued TPS, the average Tier 1 ratio would be much lower, at just 9.5\%. This result implies that banks with rapid asset growth issue TPS to keep regulatory capital levels close to their targets.

In all but the last regression in Table 3, insider ownership has a hazard ratio significantly greater than 1. This result is not predicted by our theory. However, it points to an additional reason why BHCs might choose to issue TPS. A fast-growing bank that has to keep issuing securities to satisfy capital requirements will dilute the ownership ratio of its insiders if it issues equity. Consequently, insiders are likely to prefer to issue TPS rather than equity in such a situation.

\section{B. TPS / Tier 1 Ratio}

We now examine the determinants of the TPS / Tier 1 ratio by using regressions in which the dependent variable is the TPS / Tier 1 ratio of a bank and the explanatory variables are bank characteristics that could affect this ratio. The ratio can vary because of growth in retained earnings and new common equity issuances that affect the denominator, or because of new TPS issuance or TPS redemptions that affect the numerator. In Table 4, specifications (1) to (4) include year-fixed effects and BHC fixed effects to control for unobserved variation at the BHC level. Because there are a number of bank-firm-years with a TPS / Tier 1 ratio of zero, specifications (5) to (7) use Tobit regressions with yearfixed effects and standard errors clustered by BHC. In addition to left-censoring at zero, specification (6) also right-censors the dependent variable at 0.25 , because Figure 4, Panel B shows a high fraction of BHCs with a TPS / Tier 1 ratio of 0.25 . Specification (7) lags the main independent variables of interest by 5 years to examine the possibility that these independent variables might be simultaneously determined with the TPS / Tier 1 ratio.

As predicted by our theory, bank holding companies with more franchise value and higher Tier 1 capital have less TPS in their Tier 1 capital. The results hold both for the firm-fixed effects regressions, where effects are estimated from within-bank variation, and for the Tobit regressions. For the firm-fixed effects regressions, we can gauge the economic magnitude of the estimated coefficients by multiplying 
them by the time-series standard deviation of franchise value (0.047) or the Tier 1 ratio (2\%). For example, in specification (4) which includes both franchise value and the Tier 1 ratio, a one (within) standard deviation increase in franchise value (Tier 1 ratio) is associated with a decrease of $0.047 \times 0.118$ $=0.006(2.00 \times 0.002=0.004)$ in the TPS / Tier 1 ratio. Relative to the median TPS / Tier 1 ratio, this is a $22 \%(16 \%)$ decrease.

In the firm-fixed effects regressions, several bank characteristics have strong predictive power for the level of the TPS / Tier 1 ratio. If a bank becomes larger and takes on more risk-weighted assets, if it has a lower return on assets, or if its deposits decrease, its TPS / Tier 1 ratio significantly increases. When banks have fast internal growth, which makes them more likely to be constrained by capital requirements, they increase their TPS / Tier 1 ratios. If idiosyncratic volatility increases, so does the TPS / Tier 1 ratio. These results corroborate our hypothesis that banks with riskier business models that are more likely to be constrained by capital requirements will use TPS more heavily. Banks with larger notional amounts of derivatives and lower past stock returns have lower TPS / Tier 1 ratios.

Surprisingly, the repurchase indicator variable is negative. By contrast, the repurchase dummy is positive in Table 3, which models a bank's first TPS issuance decision. One possible explanation for this result is that regulators impose limits on how much stock a bank may repurchase in a given quarter. Specifically, the amount of a bank's common stock must not drop below the amount of common stock outstanding at the beginning of the quarter. To test whether this constraint was binding during the sample period, we limit the sample to periods of positive TPS issuance, and calculate the mean TPS issuance and the mean change in common stock for these periods. We find evidence that regulatory constraints on stock repurchases are binding. The average net TPS issuance of $\$ 83$ million is over six times the average change in common stock of $\$ 13$ million. In other words, BHCs that issued TPS did not repurchase common stock on net at the same time. More important, the maximum amount of stock that a bank could 
repurchase in a given period and still meet regulatory requirements was far below the amount of TPS that banks issued, suggesting that stock repurchases were not the main use of TPS funds. ${ }^{18}$

Columns (5) to (7) show results from Tobit panel regressions. Large internationally active bank holding companies were initially encouraged and, after 2004, were restricted by regulators to have a lower TPS / core capital ratio (up to $15 \%$ instead of $25 \%$ ) than other banks. We create an indicator variable equal to one if a BHC has total assets larger than $\$ 250$ billion or if the Federal Reserve Statistical Release "Large Commercial Banks” shows that the main subsidiary bank of the BHC has more than $\$ 10$ billion in foreign assets. ${ }^{19}$ The results for franchise value and the Tier 1 ratio in Column (5) are economically larger than for the fixed effects regressions. A one standard deviation increase in franchise value is associated with a $2.8 \%$ decrease in the TPS / Tier 1 ratio. A one standard deviation increase in the Tier 1 ratio is associated with a 5.9\% decrease in the TPS / Tier 1 ratio. As expected, the indicator variable for a large bank is negative and economically large (but not statistically significant): Internationally active banks have about 10.7\% less TPS / Tier 1 than other banks. Most other bank characteristics have the same explanatory power as in the firm-fixed effect regressions. In Column (6), we right-censor the dependent variable at 0.25 since we observe clustering at this level of the TPS / Tier 1 ratio. ${ }^{20}$ The upper limit has almost no effect on the estimated coefficients and their statistical significance. Column (7) shows results if we substitute lagged franchise value and Tier 1 ratio with franchise value and

\footnotetext{
${ }^{18}$ Further, when we redo the tests of Table 4 year by year, we find evidence of a positive relationship between TPS issuance and repurchase activity for the first two years of the sample period (consistent with Benston et al (2003)), but a negative relationship for the rest of the period, indicating that for most of the sample period firms are not using TPS for repurchases. This finding also helps explain the positive coefficient on repurchases in Table 3, which models the initial TPS issuance decision; early TPS issuance is more likely to be used for repurchases than subsequent TPS issuance.

${ }^{19}$ Internationally active BHCs are defined as those with over $\$ 250$ billion in assets or $\$ 10$ billion in foreign exposure. There is, to the best of our knowledge, no publicly available list of these banks, because the Federal Financial Institutions Examination Council's (FFIEC) country exposure report on foreign assets is not in the public domain. The Federal Reserve maintains a web page where it lists the largest US commercial banks and the fraction of domestic assets they hold, by quarter. These data are however for the depository bank subsidiaries and not for the bank holding companies. Hence, our procedure misses those BHC with less than $\$ 250$ billion in total assets in which the main subsidiary bank does not hold $\$ 10$ billion in foreign assets but the BHC does on a consolidated basis. Because there are only 10 or so internationally active banks each year, these missing internationally active BHC are unlikely to make a difference in the regressions.

${ }^{20}$ The regulatory upper limit for TPS / Tier 1 is not exactly 0.25 since the regulatory limit is based on core capital, not Tier 1 regulatory capital. However, observations cluster at this threshold, which is why we use it. Changing the upper limit to 0.33 does not qualitatively or quantitatively change our conclusions.
} 
Tier 1 ratio that are lagged by five years. We use this specification to reduce concerns that TPS / Tier 1 and our proxies for constrained banks may be jointly determined by some unobserved time-varying characteristics. Lagged franchise value and the lagged Tier 1 ratio continue to be statistically and economically highly significant.

\section{Regulatory Arbitrage and Asset Backed Commercial Paper}

Hypothesis 2 predicts that a constrained bank will use all available opportunities to optimize its level of risk. We next relate TPS-based regulatory arbitrage to another type of regulatory arbitrage. Acharya, Schnabl, and Suarez (2013) argue that banks used asset backed commercial paper (ABCP) conduits as a form of regulatory arbitrage during the 2000s. These conduits allowed banks to move assets off their balance sheets, which improved their Tier 1 ratios by reducing risk-weighted assets (the denominator of the Tier 1 ratio). However, banks generally retained the risk associated with these assets by providing liquidity or credit guarantees should the underlying assets fail to roll over and/or default. Similar to our results for trust preferred securities, we find that capital constrained banks had more conduit exposure than other banks.

We examine whether the same banks that used ABCP for regulatory arbitrage were also significant users of TPS, thereby using both instruments to increase their probability of default given the regulatory context. In Appendix B, we list the names of banks with conduit exposure at any point during the sample period, based on four items reported in Forms FR Y-9C since $2001 .^{21}$ Appendix B also provides detail on whether banks have TPS outstanding during the period, and the average size of the bank's assets and ABCP exposure, sorted in order of total sponsored ABCP exposure. These data differ from Acharya, Schnabl, and Suarez (2013) in that the Form FR Y-9C data provide detail on the guarantees on both

\footnotetext{
${ }^{21}$ Item BHCKB806 reports the maximum contractual credit exposure remaining for conduits sponsored by the bank or bank affiliate, and BHCKB807 reports the same information for conduits sponsored by other institutions. BHCKB808 reports the unused facilities for liquidity protection for conduits sponsored by the bank or affiliate, and BHCKB809 reports unused liquidity facilities for conduits sponsored by other institutions.
} 
sponsored and other conduits. Additionally, we list all banks with conduit exposure, not just those with assets greater than $\$ 50$ billion at the end of 2006 .

As in Acharya, Schnabl, and Suarez (2013), most ABCP exposure is with a few large banks. Because of economies of scale, a bank is more likely to use TPS than ABCP as a means of regulatory arbitrage. However, if a bank uses ABCP, we would expect it to also use TPS. This turns out to be true. All but one of the banks that have sponsored ABCP also have TPS.

In unreported tests, we redo the analyses from Table 4, adding ABCP / risk-weighted assets as an independent variable. Since ABCP data is only available since 2001, this reduces the sample size. There is a positive relationship between ABCP usage and high levels of TPS / Tier 1, which is significant at the $10 \%$ level or better in 5 of the 7 regression specifications. Therefore, the overlap between TPS and ABCP that we document in Appendix B is borne out in a more rigorous regression model, implying that these constrained banks are more likely to have ABCP conduits.

Table 5 performs a more direct test of the relationship between the propensity for constrained banks to increase their probability of default and $\mathrm{ABCP}$ usage. We regress $\mathrm{ABCP}$ usage on our proxies for whether banks are constrained and control variables. The dependent variable is one of three measures of ABCP usage in the spirit of Acharya, Schnabl, and Suarez (2013): Total ABCP / risk-weighted assets, credit protection $\mathrm{ABCP} /$ risk-weighted assets, and liquidity protection $\mathrm{ABCP} /$ risk-weighted assets. $^{22}$ The control variables are as in Acharya, Schnabl, and Suarez (2013) and include the log of total assets, short-term debt / assets, loans / assets, and deposits over assets as well as year-fixed effects. In addition to fixed-effects regressions, we also estimate Tobit regressions, since the ABCP variable suffers from leftcensoring. In all six specifications, the coefficients on the Tier 1 ratio are significantly negative, indicating strong support for the hypothesis that constrained banks use ABCP to increase their probability of default. The economic significance is high. Taking the results from Column (1), the coefficient on the Tier 1 ratio is -0.017 . Given the mean and standard deviation of $0.17 \%$ and $1 \%$ respectively, this implies a

\footnotetext{
${ }^{22}$ Acharya, Schnabl, and Suarez (2013) scale their dependent variable by equity. Our results are robust to this alternative specification.
} 
$10 \%$ decrease in $\mathrm{ABCP}$ / risk-weighted assets for every 1\% increase in the Tier 1 ratio. Further, consistent with Acharya, Schnabl, and Suarez (2013), the results are stronger for liquidity protection ABCP facilities compared to credit protection facilities. However, the coefficient on franchise value is not significant. Therefore, one of our proxies for being constrained is strongly linked to ABCP issuance (Tier 1 ratio), while the other (franchise value) is not. In an attempt to explain this result, we note that only large banks issue $\mathrm{ABCP}$, and that franchise value is fairly homogeneous for large banks. There may not be enough time-series and cross-sectional variation to reliably identify the relation between ABCP issuance and franchise value. $^{23}$

Our results provide strong evidence that the same banks that use TPS to increase the numerator of their Tier 1 ratio also use ABCP to decrease the denominator of their Tier 1 ratio. Both activities are a form of regulatory arbitrage that allows constrained banks to move closer to their desired probability of default without a reduction in Tier 1 capital.

\section{E. TPS and bank risk}

We now analyze our third and fourth hypotheses, which posit that banks with TPS are riskier (Hypothesis 3) and that this riskiness will lead to bigger problems if banks experience a negative shock (Hypothesis 4). Note that our theory does not predict that higher riskiness is due to TPS alone. Rather, with our theory, banks engage in regulatory arbitrage so that they can be riskier than they would be in the absence of regulatory arbitrage. We first investigate whether banks with TPS have a smaller distance to default during our sample period. The distance to default is a standard measure to estimate the probability of default of a firm. Next, keeping regulatory capital constant, we would expect banks with more TPS to be more adversely affected by large negative shocks. We test this proposition using the financial crisis of 2007/2008. We would expect banks with more TPS to be more affected by the crisis. An alternative hypothesis is that safer banks require a smaller cushion to protect them from shocks, so that they would

\footnotetext{
${ }^{23}$ In unreported regressions, we repeat the analysis of Table 5 and restrict our sample to large banks only (over \$15 billion in assets). The effect of the Tier 1 ratio remains statistically and economically significant. We also perform regressions that include a dummy variable for banks over $\$ 15$ billion in assets, and the results are unchanged.
} 
use TPS because it enables them to reduce the cushion they require. With this alternative hypothesis, there would no reason for banks with TPS to be affected more by the crisis. We show that first, banks with more TPS were more likely to use the Troubled Asset Relief Program (TARP) and that second, these banks had worse accounting and stock return performance during the crisis.

\section{E.1. Distance to Default and TPS Usage}

We first examine whether TPS usage is correlated with a common proxy for bank risk from 1996 to 2011. Our measure of risk is the bank’s z-score, a distance-to-default measure. We follow Boyd, Graham, and Hewitt (1993) and Laeven and Levine (2009) and calculate the z-score as the ratio of the return on assets plus the capital-asset ratio divided by the standard deviation of the return on assets, where capital is the market value of equity. The standard deviation of ROA is calculated using six years of quarterly data. A higher z-score indicates that the bank is further away from default. The mean and median z-scores ( $\log (\mathrm{z}$-score) $)$ of our sample banks are 17.84 and 18.35 (2.75 and 2.93), which are comparable to the means reported in Laeven and Levine (2009) for the U.S. ${ }^{24}$ Table 6 reports regressions of the z-score on our measure of TPS / Tier 1 capital and control variables. The table shows that banks with more TPS had a significantly lower distance to default, using both the z-score or $\log (\mathrm{z}$-score) measure. The effect is economically important. A one standard deviation increase in TPS / Tier 1 (0.117) is associated with a decrease in the z-score of 0.47 . The effects are similar in economic magnitude if we use the log measure in Columns (3) and (4). As for the other explanatory variables, we find that better capitalized banks, banks with better returns in the prior year, banks with lower idiosyncratic volatility, banks with lower book-to-market ratios, banks with a less correlated loan portfolio, and banks with lower asset growth have a larger distant to default.

\footnotetext{
${ }^{24}$ Although the distribution of the z-score measure in our sample is not too skewed, we report regression results for both the z-score and $\log$ (z-score) for better comparability to other studies. Most papers including Laeven and Levine (2009) report results using $\log (\mathrm{z}$-score).
} 


\section{E.2. TARP and TPS Usage}

Our fourth hypothesis is that banks with a higher ratio of TPS / Tier 1 are riskier, so that we would expect them to have been affected more strongly by the financial crisis. One measure of the impact of the crisis on a bank is whether it received TARP funding. The TARP was authorized by the U.S. Congress on October 3, 2008 to strengthen the financial sector. Our focus is on the Capital Purchase Program (CPP), the direct government purchase of newly issued preferred stock of BHCs. Eligible institutions were permitted to sell equity to the Treasury in amounts of 1 percent to 3 percent of the institution's riskweighted assets. The Treasury spent about \$205 billion on the CPP from the start of the plan in October 2008 to the final distribution in December 2009. Most financial institutions participating in the CPP paid a five percent dividend on preferred shares for the first five years and a nine percent rate thereafter. In addition, Treasury received warrants to purchase common shares or other securities from the banks at the time of the CPP investment. ${ }^{25}$

Of the 382 banks in our sample at the start of the crisis in July 2007, 174 received CPP funding. For our analysis, we drop six of these banks that were among the initial recipients of CPP since these banks were strongly encouraged to participate in the program by Secretary of the Treasury Paulson. ${ }^{26}$ Results do not change if we include these banks. Of the remaining 168 banks, the average CPP funding per bank in the sample was $\$ 265$ million and the median was $\$ 40$ million. Since our hypotheses predict that banks with higher levels of TPS / Tier 1 are more likely to suffer during a financial crisis, we predict that these banks will be more likely to use the CPP program. Table 7 presents results of a probit regression in which the dependent variable is set to 1 if the bank receives CPP funding between October 2008 and December 2009, and zero otherwise. The independent variables are measured pre-crisis, as of June 2007. The main

\footnotetext{
${ }^{25}$ See http://www.treasury.gov/initiatives/financial-stability/TARP-Programs/bank-investmentprograms/cap/Pages/overview.aspx for more details.

${ }^{26}$ These banks include Bank of America, Bank of New York, Citibank, JP Morgan, State Street, and Wells Fargo. On October 13, 2008, U.S. Treasury secretary Paulson requested these banks accept TARP money, stating in a memo to the banks, "We don't believe it is tenable to opt out because doing so would leave you vulnerable and exposed. If a capital infusion is not appealing, you should be aware your regulator will require it in any circumstance.” Three investment banks - Goldman Sachs, Merrill Lynch, and Morgan Stanley - also received this initial request, but are not in the sample as of 2007 since they were not bank holding companies at the time. For more detail, see http://uk.reuters.com/article/2009/05/14/us-financial-banks-meeting-idUKTRE54D0NH20090514.
} 
variable of interest is TPS / Tier 1. Regressions also include a set of control variables used in prior literature (see, for example, Duchin and Sosyura (2012)). These variables include either the Tier 1 ratio or the regulatory leverage ratio, which is Tier 1 / Total Assets. Since these variables have a correlation coefficient of 0.75 , they are included in separate regressions. Regressions also include the log of total assets to control for size, idiosyncratic volatility and beta to control for risk, a bank’s book to market ratio, prior year stock performance and ROA, and the prior three-year mean of asset growth. ${ }^{27}$

The results presented in Table 7 provide strong evidence that the banks that use TPS are more likely to use the CPP program. The effects are economically large and statistically significant. In Column (2), a one standard deviation increase in TPS / Tier $1(0.117)$ is associated with a 9.8\% $(0.117 x 0.841=0.098)$ higher chance of receiving TARP funds. The Tier 1 capital ratio is strongly negatively related to CPP use, and the regulatory leverage ratio is weakly negatively related to CPP use, implying that better-capitalized banks are less likely to participate in the CPP. The other control variables are mostly insignificant. Banks that used TPS were more likely to need government assistance during the financial crisis, consistent with our hypothesis that these banks are riskier. ${ }^{28}$

In untabulated regressions, we use the actual dollar amount of CPP funding as a fraction of Tier 1 capital instead of a CPP indicator variable. The results are statistically significant and economically large. For example, in a regression that mimics Column (2) of Table 7, we find that a one standard deviation increase in TPS / Tier 1 increases the ratio of CPP funding / Tier 1 by 2.6\%, or 19\% relative to the mean CPP funding / Tier 1 ratio of 0.135 .

\footnotetext{
${ }^{27}$ Results are robust to the inclusion of an indicator variable set to one if the bank is internationally active to control for different TPS requirements for those banks.

${ }^{28}$ An obvious additional question is whether banks with higher levels of TPS were more likely to fail during or after the crisis. However, the existence of CPP and a host of other government programs made failure less likely during the crisis, especially among the largest banks. We perform a t-test for differences in TPS / Tier 1 for banks that fail between July 2007 and December 2009 and find that banks with higher TPS / Tier 1 ratios are more likely to fail. However, this analysis does not hold up to a multivariate regression analysis, likely because of the existence of government programs that prevented failures.
} 


\section{E.3. Crisis Performance and TPS Usage}

Next, we evaluate the relation between bank performance during the financial crisis and TPS usage. Our hypothesis predicts that banks with high levels of TPS should perform worse during the crisis. We evaluate both stock price performance and operating performance (return on assets before income taxes). We consider the performance of BHCs from July 1, 2007 to December 31, 2008 to correspond to the returns during the crisis. These results are robust to alternative crisis ending dates of March 31, June 30, or September 30, 2009. As in Table 7, all explanatory variables are measured prior to the crisis as of June 30, 2007.

Table 8 shows results. The first three columns show results for stock market performance for the period July 2007 to December 2008, and the next three columns show results for return on assets over the same time period. In Column (1), which includes just the TPS / Tier 1 ratio, the coefficient on TPS / Tier 1 is negative and strongly statistically significant. The coefficient loses its significance in Column (2) when we include the Tier 1 ratio and a number of other controls. However, in Column (3), which includes regulatory leverage as a control variable, the coefficient on TPS / Tier 1 is negative and strongly statistically significant. In terms of economic magnitude, a one standard deviation increase in the TPS / Tier 1 ratio (0.106) decreases annualized crisis returns by 2.9\%. Relative to the sample BHC’s annualized crisis return of $-25.2 \%$, this corresponds to an $11.5 \%$ lower return. For the ROA regressions in Columns (4) to (6), the coefficient on TPS / Tier 1 is negative and statistically significant regardless of the control variables used. As with the stock performance regressions, the economic magnitude is meaningful. The average BHC has an annualized ROA of $0.86 \%$. A one standard deviation increase in TPS / Tier 1 decreases ROA by $0.29 \%(0.106 *(-0.028))$ in Column (5) (with the Tier 1 ratio as a control variable) and 0.33\% in Column (6) (which includes the leverage ratio as a control variable). Relative to the sample mean, these correspond to 34\% and 39\% lower returns, respectively.

The control variables in the stock return regressions are of the expected sign and consistent with recent findings. Small banks and banks with high Tier 1 ratios performed better during the crisis. Banks with high idiosyncratic volatility, high book to market ratios, more concentrated loan portfolios, and high 
growth over the past three years did worse during the crisis. Finally, there is some evidence that bank holding companies with higher betas did better during the crisis. ${ }^{29}$ For the ROA regressions, we find that bank holding companies that are larger, have higher book-to-market ratios, higher growth over the past three years, and more concentrated loan portfolios had worse performance during the crisis.

\section{Conclusion}

Our paper provides a theory for why some banks engage in regulatory arbitrage and others do not. Our theory is that banks have different optimal levels of risk depending on their franchise values. Banks with high franchise values find it optimal to have low levels of risk and high levels of capital. These banks are unconstrained by capital requirements. In contrast, banks with low franchise values find it optimal to have high levels of risk and low levels of capital. Such banks are constrained by capital requirements. Constrained banks take actions to relax these constraints when possible. Therefore, we predict that constrained banks will use regulatory arbitrage, such as issuing TPS. TPS allows constrained banks to satisfy capital requirements with more risk than banks that do not issue TPS. Effectively, a bank with TPS in its regulatory capital is more levered than a bank that has the same amount of regulatory capital comprised solely of common equity. Since TPS are a combination of equity and debt, replacing equity with TPS amounts to an increase in the bank's debt.

We show that banks that use trust preferred securities have lower franchise values and Tier 1 capital ratios. Consistent with our theory, we also show that banks that issue TPS are more likely to engage in other forms of regulatory arbitrage such as using ABCP conduits. We expect banks that issue more TPS to be riskier than other banks, and we find that banks with more TPS have a smaller distance-to-default during our sample period. We also expect riskier banks to have been more fragile during the financial crisis and show that, everything else equal, a bank that had more TPS in its capital structure was more likely to receive TARP funding and had worse stock performance during the 2007 crisis.

${ }^{29}$ This finding is consistent with Fahlenbrach, Prilmeier, and Stulz (2012). See their paper for a potential explanation of this somewhat surprising finding. 


\section{References}

Acharya, Viral V., Irvind Gujral, and Hyun Song Shin, 2009, Dividends and bank capital in the financial crisis of 2007-2009, New York University, Working Paper.

Acharya, Viral V., Philipp Schnabl, and Gustavo Suarez, 2013, Securitization without risk transfer, Journal of Financial Economics 107, 515-536.

Arena, Matteo P., 2011, The corporate choice between public debt, bank loans, traditional private debt placements, and 144A debt issues, Review of Quantitative Finance and Accounting 36, 391-416.

Balasubramanian, Bhanu, and Ken B. Cyree, 2010, Why do banks issue trust preferred securities?, University of Mississippi, Working Paper.

Beltratti, Andrea, and René M. Stulz, 2012, The credit crisis around the globe: Why did some banks perform better?, Journal of Financial Economics 105, 1-17.

Benston, George, Paul Irvine, Jim Rosenfeld, and Joseph F. Sinkey, Jr., 2003, Bank capital structure, regulatory capital and securities innovations, Journal of Money, Credit and Banking 35, 301-322.

Berger, Allen N., 1995, The relationship between capital and earnings in banking, Journal of Money, Credit and Banking 27, 432-456.

Berger, Allen N., and Christa H.S. Bouwman, 2013, How does capital affect bank performance during financial crises?, Journal of Financial Economics 109, 146-176.

Berger, Allen N., Robert DeYoung, Mark J. Flannery, David Lee, and Özde Öztekin, 2008, How do large banking organizations manage their capital ratios?, Journal of Financial Services Research 34, 123149.

Berlin, Mitchell, 2011, Can we explain banks’ capital structures?, Philadelphia Fed Business Review Q2 2011, 1-12.

Boyd, John H., Stan Graham, and Shawn Hewitt, 1993, Bank holding company mergers with nonbank financial firms: Effects of the risk of failure, Journal of Banking and Finance 17, 43-63. 
Cordell, Larry, Michael Hopkins, and Yilin Huang, 2011, The trust preferred CDO market: From start to (expected) finish, Federal Reserve Bank of Philadelphia Working Paper 11-22.

DeAngelo, Harry, and René M. Stulz, 2014, Liquid-claim production, risk management, and capital structure: Why high leverage is optimal for banks, working paper, Ohio State University.

Demirguc-Kunt, Asli, Enrica Detragiache, and Ouarda Merrouche, 2013, Bank capital: Lessons from the financial crisis, Journal of Money, Credit and Banking 45, 1147-1164.

Demsetz, Rebecca S., Marc R. Saidenberg, and Philip E. Strahan, 1996, Banks with something to lose: The disciplinary role of franchise value, Federal Reserve Bank of New York Policy Review, 1-14.

Duchin, Ran, and Denis Sosyura, 2012, The politics of government investment, Journal of Financial Economics 106, 24-48.

Emanuel, David, 1983, A theoretical model for valuing preferred stock, Journal of Finance 38, 11331155.

Engel, Ellen, Merle Erickson, and Edward Maydew, 1999, Debt-equity hybrid securities, Journal of Accounting Research 37, 249-274.

Fahlenbrach, Rüdiger, Robert Prilmeier, and René M. Stulz, 2012, This time is the same: Using bank performance in 1998 to explain bank performance during the recent financial crisis, Journal of Finance 67, 2139-2185.

Flannery, Mark J., and Kasturi P. Rangan, 2008, What caused the bank capital buildup of the 1990s?, Review of Finance 12, 391-429.

French, George E., Andrea N. Plante, Eric W. Reither, and Ryan D. Sheller, 2010, Trust preferred securities and the capital strength of banking organizations, Supervisory Insights 7, 3-16

Gorton, Gary, and Andrew Winton, 2000, Liquidity provision, bank capital, and the macroeconomy, University of Minnesota, Working Paper.

Harvey, Keith, M. Cary Collins, and James W. Wansley, 2003, The impact of trust-preferred issuance on bank default risk and cash flow: Evidence from the debt and equity securities markets, Financial Review 38, 235-256. 
Hovakimian, Armen, and Edward J. Kane, 2000, Effectiveness of capital regulation at U.S. commercial banks, 1985 to 1994, Journal of Finance 55, 451-468.

Jackson, Patricia, 1999, Capital requirements and bank behavior: The impact of the Basle Accord, Basle Committee on Banking Supervision, Working Paper.

Keeley, Michael C., 1990, Deposit insurance, risk, and market power in banking, American Economic Review 80, 1183-1200.

Kim, Dong H., and Duane Stock, 2012, Impact of the TARP financing choice on existing preferred stock, Journal of Corporate Finance 18, 1121-1142.

Krishnan, C.N.V., and Paul A. Laux, 2005, Misreaction, Journal of Financial and Quantitative Analysis 40, 403-434.

Laeven, Luc, and Ross Levine, 2009, Bank governance, regulation, and risk-taking, Journal of Financial Economics 93, 259-75.

Marcus, Alan J., 1983, The bank capital decision: A time series - cross section analysis, Journal of Finance 38, 1217-1232.

Marcus, Alan J., 1984, Deregulation and bank financial policy, Journal of Banking and Finance 8, 557565.

Matten, Chris, 2000, Managing Bank Capital: Capital Allocation and Performance Measurement, John Wiley \& Sons, Chichester, UK, $2^{\text {nd }}$ edition.

Mehran, Hamid, and Anjan Thakor, 2011, Bank capital and value in the cross-section, Review of Financial Studies 24, 1019-1067.

Merton, Robert C., 1974, On the pricing of corporate debt: The risk structure of interest rates, Journal of Finance 29, 449-470.

Thakor, Anjan, 2013, Bank capital and financial stability, EGCI, Working Paper.

Vassalou, Maria, and Yuhang Xing, 2004, Default risk in equity returns, Journal of Finance 59, 831-868. 


\section{Appendix A: Description of Tier 1 Capital}

The following description of Tier 1 capital is based on the Bank Holding Company Act, Section 6000 FDIC Law. ${ }^{30}$

Tier 1 capital is defined as the sum of core capital elements less any amounts of goodwill, other intangible assets (except for certain mortgage servicing rights), credit-enhancing interest-only strips receivables, deferred tax assets, and nonfinancial equity investments. Core capital elements include common stockholders' equity, qualifying noncumulative perpetual preferred stock, senior perpetual preferred stock issued under TARP (for 2008 forward), minority interest related to qualifying common or noncumulative perpetual preferred stock directly issued by a consolidated U.S. depository institution or foreign bank subsidiary (Class A minority interest), and restricted core capital elements. Restricted core capital elements include qualifying cumulative perpetual preferred stock, minority interest related to qualifying cumulative perpetual preferred stock directly issued by a consolidated U.S. depository institution or foreign bank subsidiary (Class B minority interest) (effective March 31, 2011), minority interest related to qualifying common stockholders' equity or perpetual preferred stock issued by a consolidated subsidiary that is neither a U.S. depository institution nor a foreign bank (Class C minority interest) (effective March 31, 2011) and qualifying trust preferred securities. ${ }^{31}$

Effective March 31, 2011, the aggregate amount of restricted core capital elements that may be included in the Tier 1 capital of a banking organization must not exceed 25\% (15\% for internationally active bank holding companies) of the sum of all core capital elements, including restricted core capital elements, net of goodwill less any associated deferred tax liability. Prior to March 31, 2011, the aggregate amount of qualifying cumulative perpetual preferred stock (including related surplus) and qualifying trust preferred securities that a banking organization may include in Tier 1 capital is limited to 25\% (15\% for internationally active bank holding companies) of the sum of the following core capital elements: qualifying common stockholders' equity, qualifying noncumulative and cumulative perpetual preferred stock (including related surplus), qualifying minority interest in the equity accounts of consolidated subsidiaries, and qualifying trust preferred securities.

\footnotetext{
${ }^{30} \mathrm{http}: / /$ www.fdic.gov/regulations/laws/rules/6000-1900.html.

${ }^{31}$ Prior to the passage of FASB 46 in 2003, minority interest was not categorized into Classes A, B, and C, and TPS were classified as minority interest. There was also no specific limit on how much of a bank's Tier 1 capital could be comprised of minority interest, with the exception of TPS, which were limited to $25 \%$ of core capital. The definition of core capital was also slightly different prior to FASB 46, and included common stockholders' equity, qualifying noncumulative perpetual preferred stock including related surplus, qualifying cumulative perpetual preferred stock including related surplus (up to a $25 \%$ of core capital limit), and minority interest in the equity accounts of consolidated subsidiaries. The concept of "restricted securities" was introduced after FASB 46.
} 


\section{Appendix B \\ List of Banks with Conduit Exposure}

\begin{tabular}{|c|c|c|c|c|c|c|c|c|}
\hline Means: 2001-2012 & & & $\underline{\mathrm{Spc}}$ & ssored $\mathrm{AF}$ & & Oth & B Bank Al & \\
\hline & Has TPS? & $\begin{array}{l}\text { Assets } \\
(\$ M M)\end{array}$ & $\begin{array}{l}\text { Liq. } \\
\text { (\$MM) }\end{array}$ & $\begin{array}{l}\text { Credit } \\
(\$ M M)\end{array}$ & $\begin{array}{l}\text { Total } \\
(\$ M M)\end{array}$ & $\begin{array}{l}\text { Liq. } \\
\text { (\$MM) }\end{array}$ & $\begin{array}{c}\text { Credit } \\
(\$ M M)\end{array}$ & $\begin{array}{l}\text { Total } \\
(\$ M M)\end{array}$ \\
\hline J.P. Morgan Chase \& Co & Yes & $1,462,148$ & 48,912 & 4,781 & 53,693 & 6,539 & 47 & 6,586 \\
\hline Citigroup, Inc. & Yes & $1,641,036$ & 50,456 & 2,071 & 52,527 & 1,681 & 5 & 1,686 \\
\hline Bank One Corporation & Yes & 290,967 & 41,144 & 1,264 & 42,408 & 3,733 & 0 & 3,733 \\
\hline Bank of America Corp. & Yes & $1,460,707$ & 37,814 & 3,672 & 41,486 & 92 & 0 & 92 \\
\hline Wachovia Corporation & Yes & 511,060 & 17,307 & 4,143 & 21,450 & 3,121 & 2,356 & 5,477 \\
\hline State Street Corporation & Yes & 117,755 & 19,522 & 1,589 & 21,111 & 0 & 0 & 0 \\
\hline Wells Fargo \& Company & Yes & $1,289,051$ & 9,358 & 18 & 9,376 & 230 & 641 & 871 \\
\hline U.S. Bancorp & Yes & 200,303 & 6,623 & 1,530 & 8,153 & 0 & 0 & 0 \\
\hline Zions Bancorporation & Yes & 38,615 & 5,738 & 134 & 5,872 & 0 & 61 & 61 \\
\hline Suntrust Banks Inc. & Yes & 160,078 & 5,319 & 509 & 5,828 & 132 & 0 & 132 \\
\hline FleetBoston Financial Corp. & Yes & 198,194 & 4,072 & 1,692 & 5,764 & 0 & 0 & 0 \\
\hline PNC Financial Services Group & Yes & 155,780 & 5,397 & 322 & 5,719 & 208 & 0 & 208 \\
\hline Compass Bancshares & Yes & 27,914 & 2,000 & 0 & 2,000 & 85 & 83 & 168 \\
\hline Fifth Third & Yes & 101,409 & 475 & 1,414 & 1,889 & 109 & 174 & 283 \\
\hline Mellon Financial Corp. & Yes & 37,300 & 1,633 & 255 & 1,888 & 632 & 0 & 632 \\
\hline Countrywide Financial Corp. & Yes & 167,842 & 0 & 1,163 & 1,163 & 0 & 429 & 429 \\
\hline National City Corporation & Yes & 134,973 & 909 & 0 & 909 & 463 & 0 & 463 \\
\hline Bank of New York Mellon Co. & Yes & 244,156 & 881 & 18 & 899 & 429 & 0 & 429 \\
\hline Кеусогр & Yes & 91,263 & 371 & 52 & 423 & 235 & 1 & 236 \\
\hline Bank of New York & Yes & 91,872 & 0 & 229 & 229 & 889 & 0 & 889 \\
\hline First Tennessee National Corp. & Yes & 22,222 & 0 & 224 & 224 & 0 & 0 & 0 \\
\hline Cit Group & No & 60,511 & 0 & 46 & 46 & 0 & 0 & 0 \\
\hline Capital One Financial Corp. & Yes & 110,695 & 0 & 35 & 35 & 0 & 678 & 678 \\
\hline Marshall and Ilsley & Yes & 31,450 & 0 & 2 & 2 & 0 & 0 & 0 \\
\hline Independent Bank Corp. & Yes & 4,833 & 0 & 1 & 1 & 0 & 0 & 0 \\
\hline Amsouth Bancorporation & No & 45,454 & 0 & 0 & 0 & 1,990 & 115 & 2,105 \\
\hline Colonial Bancgroup & Yes & 23,400 & 0 & 0 & 0 & 735 & 68 & 803 \\
\hline First Community Bancshares & Yes & 2,273 & 0 & 0 & 0 & 0 & 14 & 14 \\
\hline Goldman Sachs Group & Yes & 917,524 & 0 & 0 & 0 & 25 & 0 & 25 \\
\hline Hibernia Corporation & No & 17,524 & 0 & 0 & 0 & 0 & 35 & 35 \\
\hline M\&T Bank Corporation & Yes & 61,188 & 0 & 0 & 0 & 0 & 24 & 24 \\
\hline Morgan Stanley & Yes & 776,179 & 0 & 0 & 0 & 2,170 & 0 & 2,170 \\
\hline People’s Mutual Holdings & No & 11,999 & 0 & 0 & 0 & 98 & 0 & 98 \\
\hline Regions Financial Corporation & Yes & 142,207 & 0 & 0 & 0 & 237 & 46 & 283 \\
\hline Susquehanna Bancshares, Inc. & No & 5,749 & 0 & 0 & 0 & 0 & 31 & 31 \\
\hline
\end{tabular}




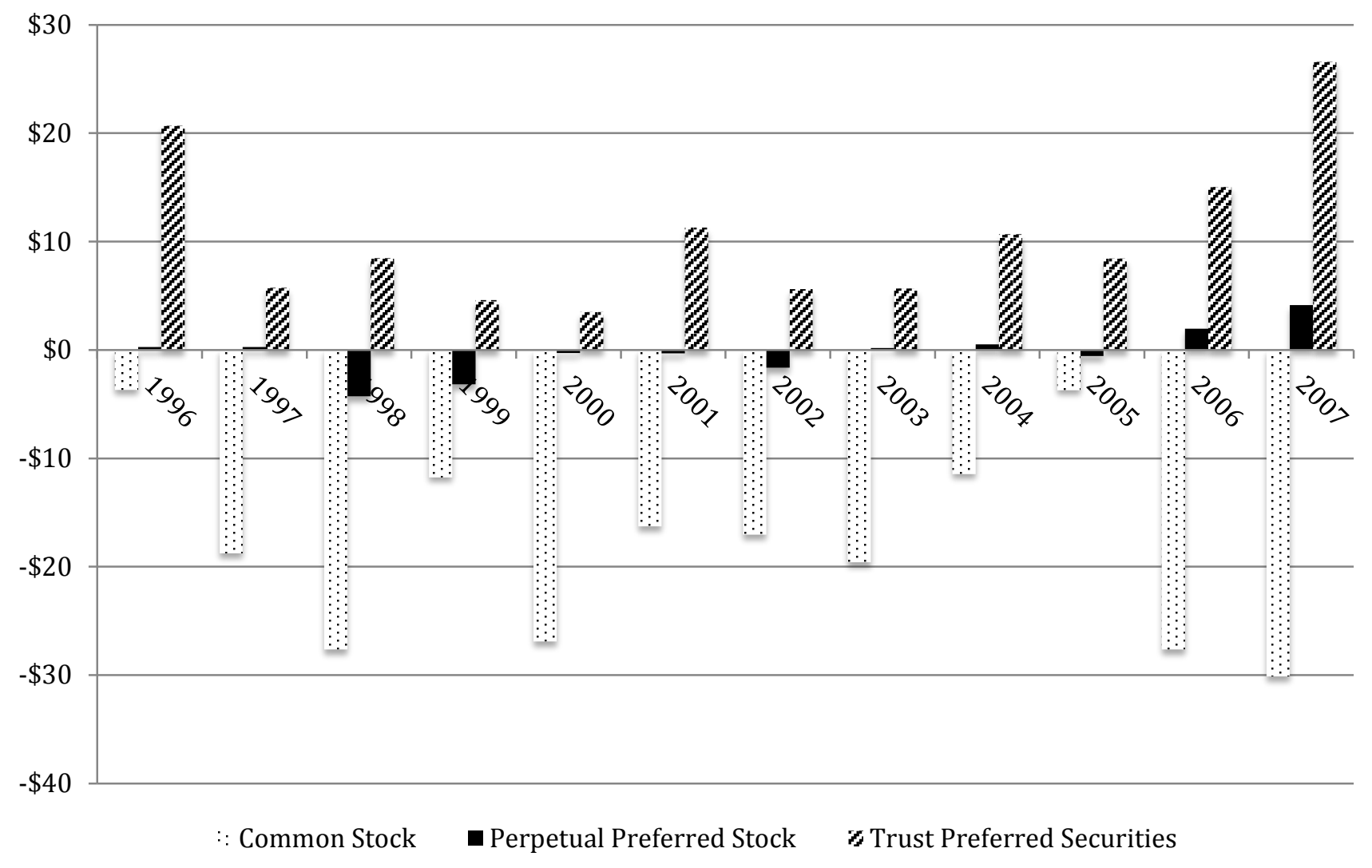

Figure 1: The figure shows the net issuance of common stock, perpetual preferred stock, and trust preferred securities by sample banks between 1996 and 2007. The y-axis shows the net issuance amounts in billions of U.S. dollars. The figure is constructed from data provided by SnL Financial. 


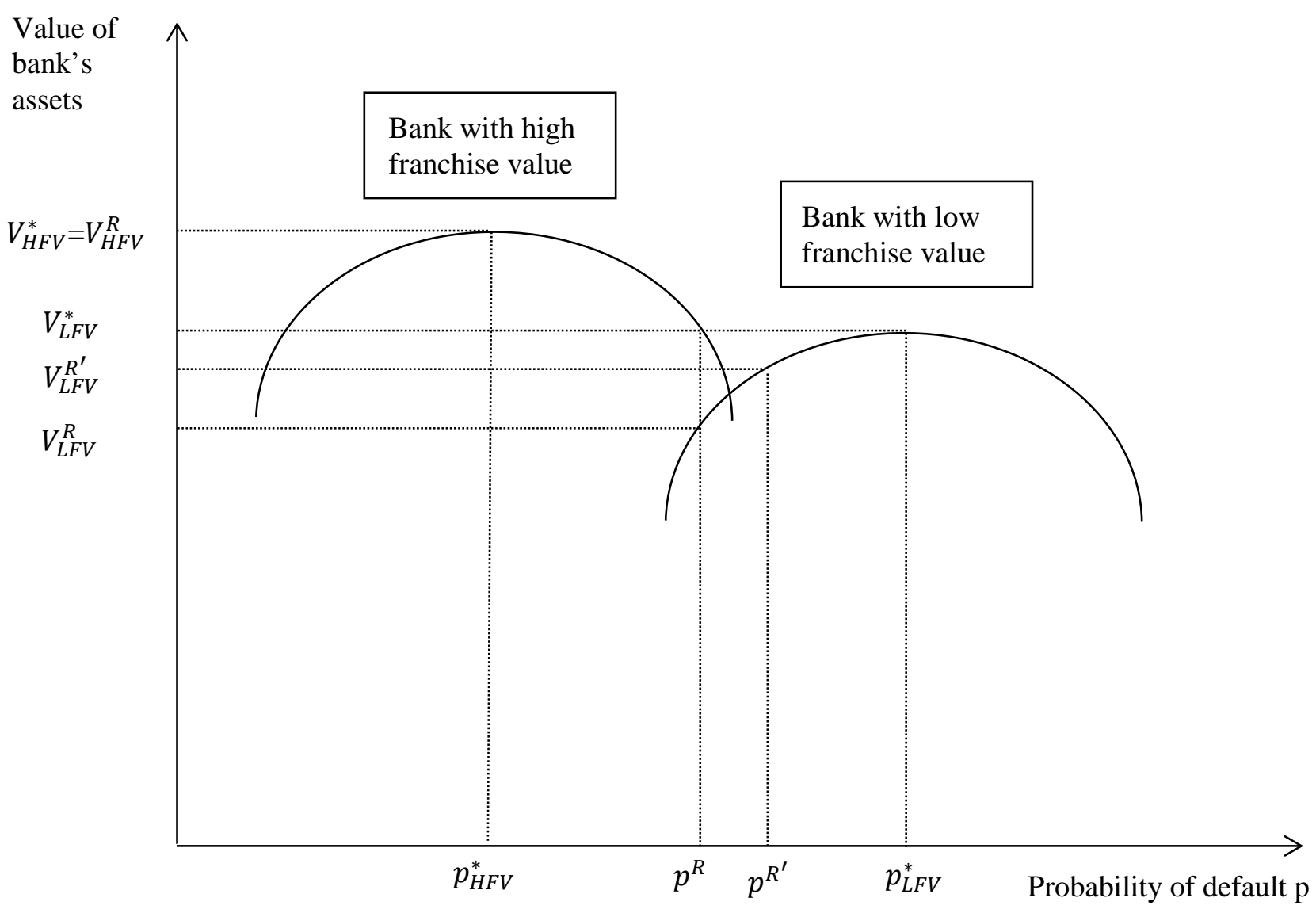

Figure 2: The figure shows the value of a bank, $\mathrm{V}$, as a function of the probability of default. The probability of default that maximizes the value of the bank is $\mathrm{p}^{*}$. The probability of default $\mathrm{p}^{\mathrm{R}}$ corresponds to the probability implied by regulatory capital requirements. The probability of default $\mathrm{p}^{\mathrm{R}}$ ' corresponds to the probability implied by regulatory capital requirements in the presence of regulatory arbitrage. The figure shows the value of a high franchise value (HFV) and low franchise value (LFV) bank. 


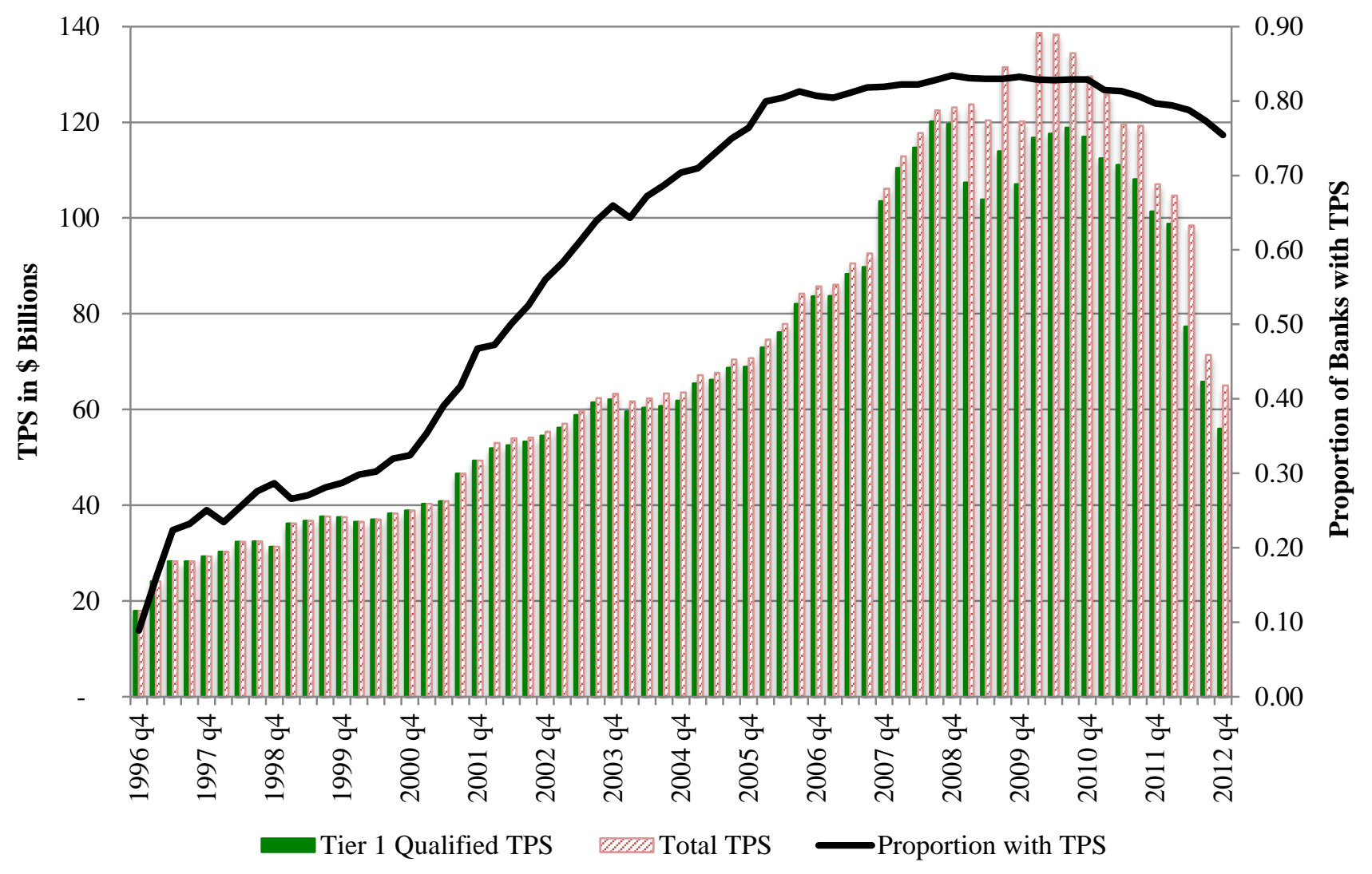

Figure 3: The figure shows the total amount of outstanding trust preferred securities (TPS) by quarter during our sample period. The solid bars show the total amount of outstanding Tier 1 qualified TPS and the shaded bars show the total amount of outstanding TPS in billions of dollars (left-hand y-axis). The black line shows the fraction of sample banks that have issued TPS for each quarter (right-hand y-axis). 


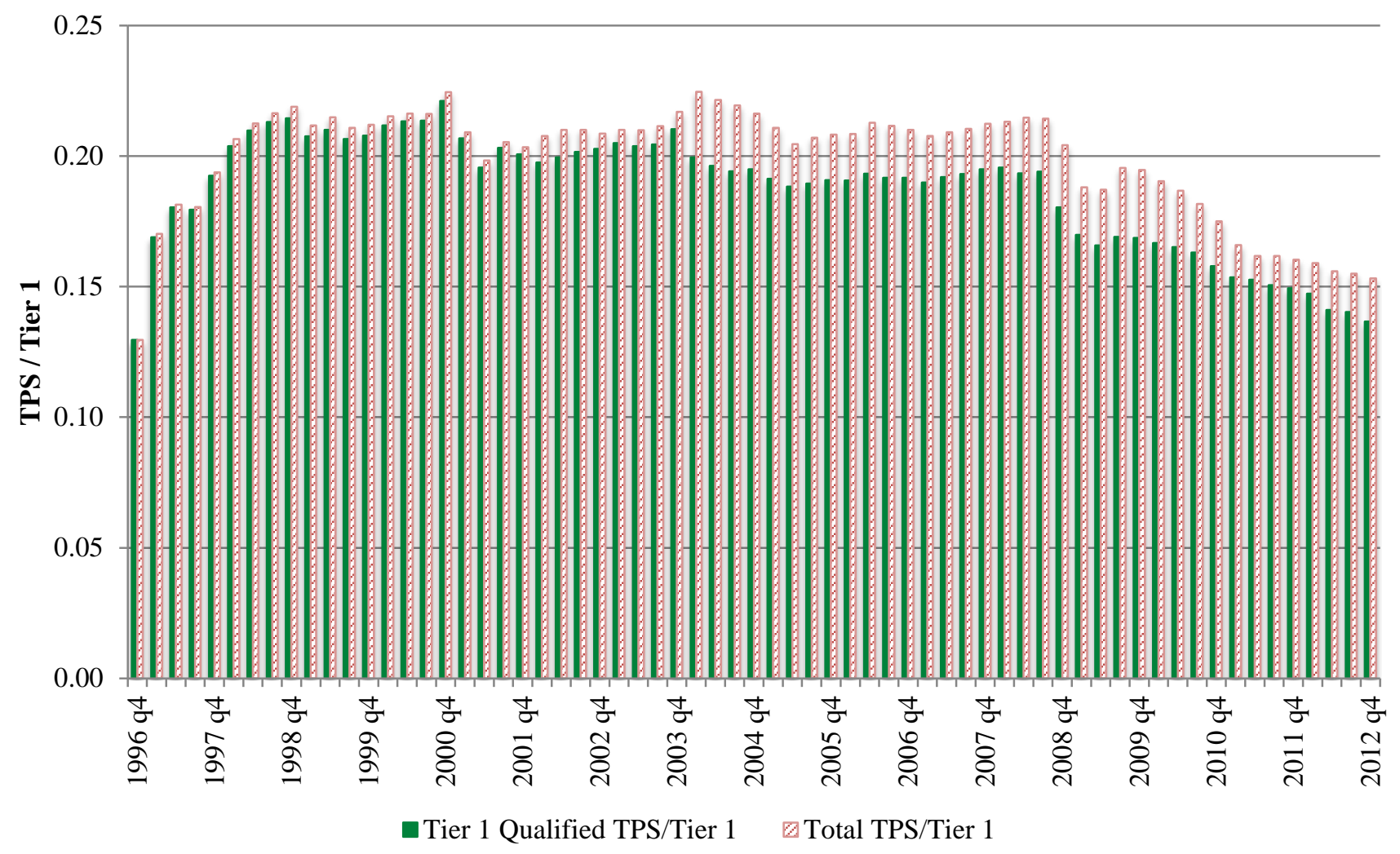

Figure 4, Panel A: The figure shows the outstanding trust preferred securities (TPS) as a fraction of Tier 1 capital by quarter during our sample period, conditional on a bank holding company having TPS outstanding in the respective quarter. The solid bars show the outstanding Tier 1 qualified TPS and the shaded bars show all outstanding TPS as a fraction of Tier 1 capital (y-axis). 


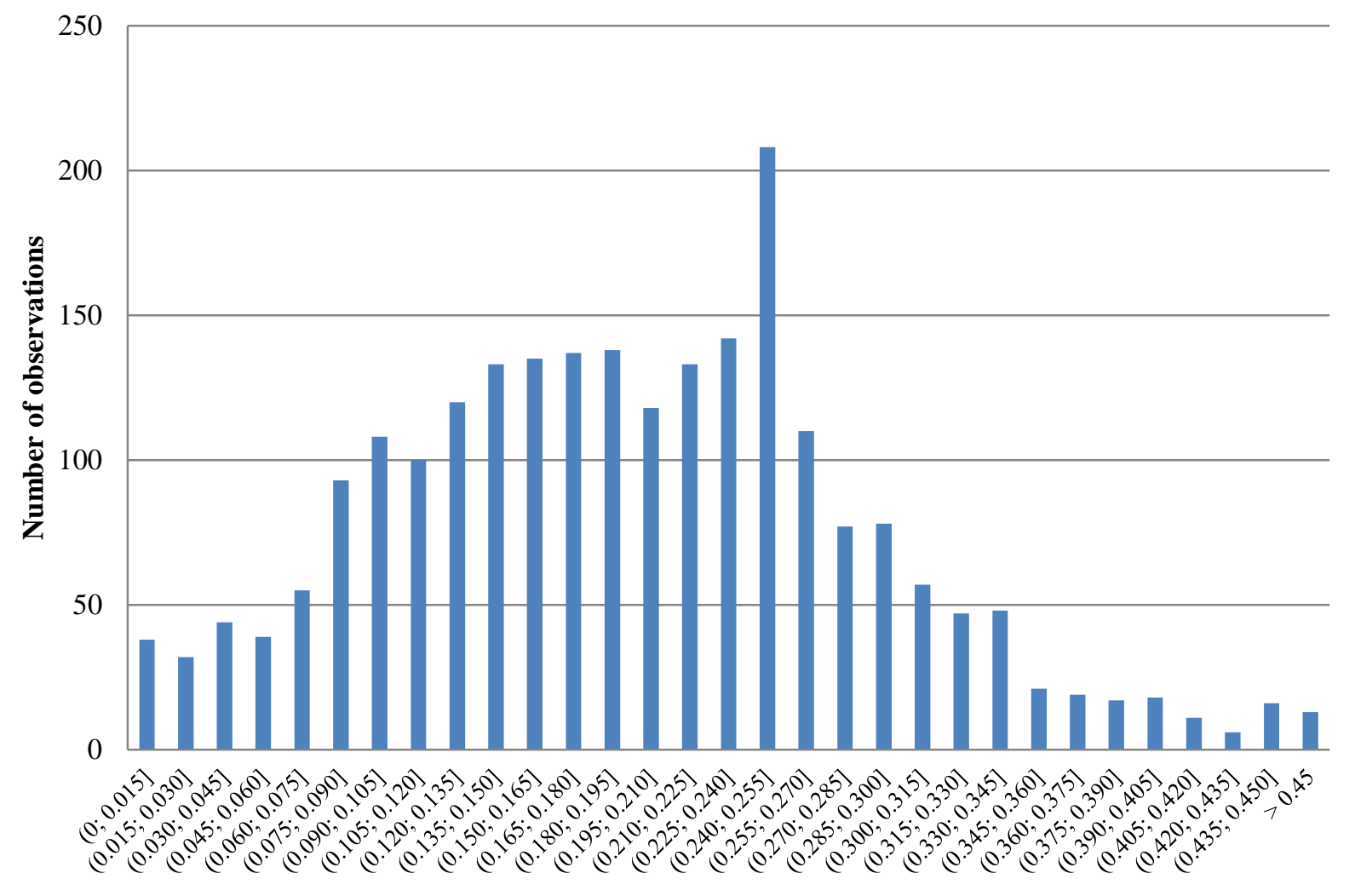

Figure 4, Panel B: The figure shows a histogram of the outstanding trust preferred securities (TPS) as a fraction of Tier 1 capital for our sample of bank holding companies (BHCs) between 1996 and 2007, conditional on a bank having TPS issued and outstanding in the respective year. Excluded from the figure are 106 BHC-year observations with total assets in excess of $\$ 250$ billion, because a different regulatory TPS/Tier 1 limit applies to them. 
Table 1: Summary Statistics at the Trust Preferred Security Level

The table reports summary statistics for trust preferred securities (TPS) issued by U.S. publicly listed bank holding companies from 1996 to 2012 . There are 1,467 unique securities. In Panel A, Number Pooled Issuances is the number of TPS that were issued as pooled TPS (also known as TPS CDOs). Number that start deferral (bank) is the number of TPS that started deferring dividends in the given year, and the number in parentheses is the number of issuing banks. Panel B reports banks' stated reasons for issuing TPS, by frequency and across all years. Panel C reports the underwriting spread of TPS issuance and other types of securities issued by sample banks. Reported is the average underwriting discount, i.e. the difference between the price paid to the issuer and the price at which the securities are sold, as a percent of the price at which the securities are sold. Values marked with ${ }^{\mathrm{a}}$ are higher than for TPS, and values marked with ${ }^{\mathrm{b}}$ are lower than for TPS, statistically significant at the $1 \%$ level based on t-tests assuming unequal variance.

\section{Panel A: Issuance Frequency, Method of Issue, and Deferral Frequency}

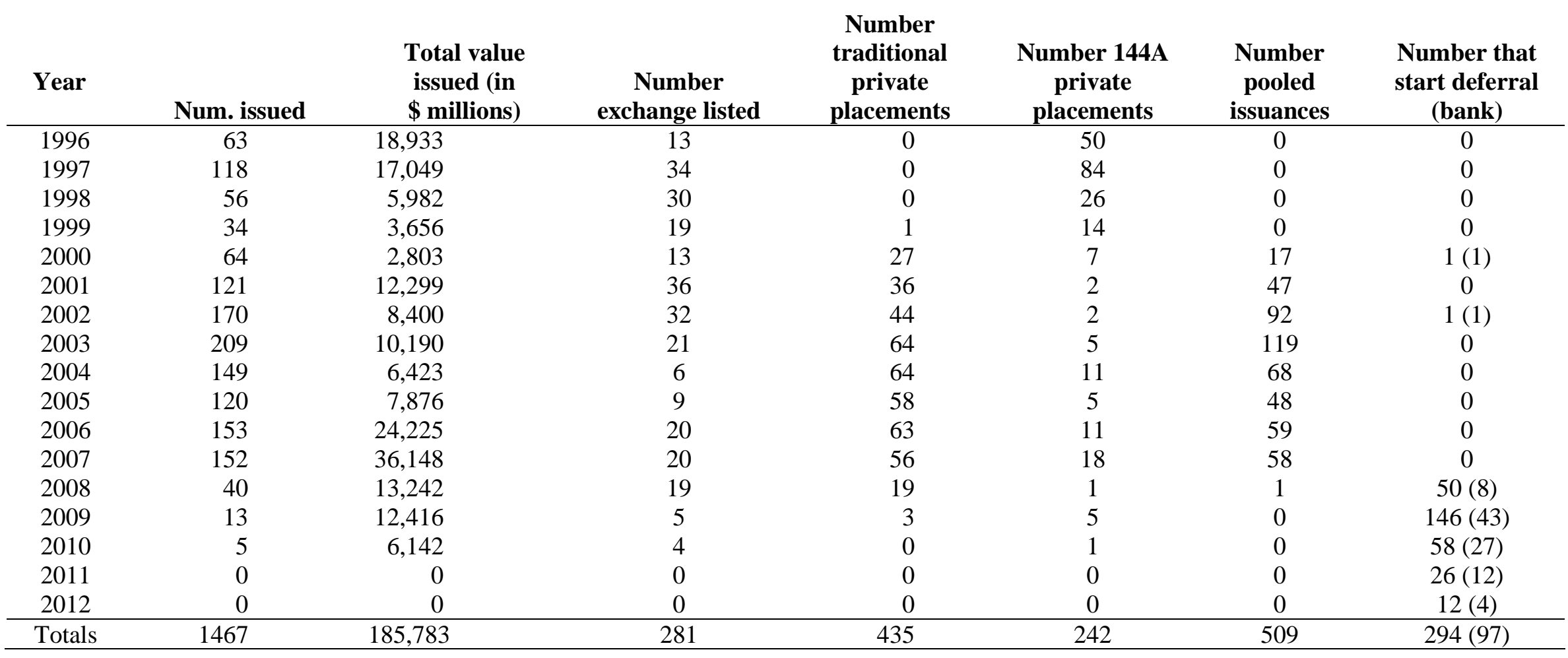


Table 1: Summary Statistics at the Trust Preferred Security Level, Continued

\begin{tabular}{lc}
\multicolumn{1}{c}{ Panel B: Stated Reasons for TPS Issuance } & Frequency \\
Reason & 240 \\
\hline To improve capital position & 236 \\
General corporate purposes & 198 \\
To fund a specific acquisition & 163 \\
To fund the redemption of existing TPS & 139 \\
To fund future growth & 78 \\
To pay down debt & 73 \\
To fund stock repurchases & 49 \\
Other (includes funding loan growth, redeeming preferred stock, and specific goals) & 291 \\
No reason stated & 1,467 \\
\hline Total & \\
\hline
\end{tabular}

Panel C: Underwriting Spread of Issuing Securities

\begin{tabular}{|c|c|c|c|c|c|c|}
\hline & Common stock & Preferred stock & Senior debt & $\begin{array}{c}\text { Senior } \\
\text { subordinated } \\
\text { debt }\end{array}$ & $\begin{array}{c}\text { Subordinated } \\
\text { debt }\end{array}$ & TPS \\
\hline Mean & $5.02^{\mathrm{a}}$ & 3.09 & $1.55^{\mathrm{b}}$ & $2.15^{\mathrm{b}}$ & $1.70^{\mathrm{b}}$ & 2.48 \\
\hline
\end{tabular}




\section{Table 2: Summary Statistics for Bank Holding Companies}

The table presents means and medians for key characteristics of the bank holding companies (BHC) in the sample from 1996 to 2012. Summary statistics are calculated by bank and then across banks, and are winsorized at the 1\%/99\% tails. Summary statistics are calculated separately for banks that never issued Trust preferred securities (TPS) during the sample period and those that issued TPS. There are 857 banks in the dataset, of which 518 issued TPS and 339 did not. Franchise value is the sum of the market value of equity and the book value of liabilities, scaled by the difference between the book value of assets and goodwill. Tier 1 ratio (\%) is the ratio of Tier 1 capital to risk-weighted assets. Regulatory Leverage Ratio is Tier 1 capital scaled by total assets. Beta is the regression coefficient from a market model of excess daily returns on the value-weighted CRSP index for the two-year period prior to the reporting date, and idiosyncratic volatility is the residual from this regression. Loan concentration index is a Herfindahl-like index measuring the concentration of the loan portfolio as in Berger and Bouwman (2013). Derivatives (trading) / assets is the gross notional principal of derivatives used for trading purposes scaled by assets, and Derivatives(other) / assets is the gross notional principal of derivatives used for purposes other than trading scaled by assets. The column difference shows the differences between the group of issuers and non-issuers. Statistically significant differences at the $10 \%, 5 \%$, and $1 \%$ level are indicated with ${ }^{*},{ }^{* *}$, and ${ }^{* * *}$ respectively.

Means Medians

TPS issuers Non-issuers Difference TPS issuers Non-issuers Difference

\begin{tabular}{|c|c|c|c|c|c|c|}
\hline \multicolumn{7}{|l|}{$\begin{array}{l}\text { Proxies for capital } \\
\text { constraints }\end{array}$} \\
\hline Franchise value & 1.058 & 1.069 & $-0.011 * * *$ & 1.051 & 1.067 & $-0.016 * * *$ \\
\hline Tier 1 ratio (\%) & 11.9 & 14.6 & $-2.7 * * *$ & 11.6 & 13.3 & $-1.7 * * *$ \\
\hline \multicolumn{7}{|l|}{ Bank characteristics } \\
\hline Total assets ( $\$$ billions) & 1,951 & 771 & $1,180 * * *$ & 1,258 & 616 & $642 * * *$ \\
\hline Risk-weighted assets / total assets & 0.732 & 0.669 & $0.063 * * *$ & 0.733 & 0.677 & $0.056^{* * *}$ \\
\hline Regulatory leverage ratio & 0.085 & 0.094 & $-0.009 * * *$ & 0.083 & 0.090 & $-0.006 * * *$ \\
\hline Insider ownership & 0.171 & 0.180 & -0.009 & 0.142 & 0.155 & -0.013 \\
\hline ROA before taxes (\%) & 1.5 & 1.9 & $-0.4 * * *$ & 1.8 & 2.2 & $-0.4 * * *$ \\
\hline Stock return & 0.072 & 0.204 & $-0.132 * * *$ & 0.076 & 0.178 & $-0.102 * * *$ \\
\hline Beta & 0.571 & 0.332 & $0.239 * * *$ & 0.488 & 0.242 & $0.246 * * *$ \\
\hline Idiosyncratic volatility (\%) & 2.5 & 2.4 & $0.1^{*}$ & 2.3 & 2.2 & $0.1^{* *}$ \\
\hline Loan concentration index & 0.594 & 0.624 & $-0.030 * * *$ & 0.592 & 0.606 & -0.014 \\
\hline Deposits / assets & 0.751 & 0.780 & $-0.029 * * *$ & 0.772 & 0.804 & $-0.032 * * *$ \\
\hline Cash / assets & 0.041 & 0.046 & $-0.005^{* * *}$ & 0.036 & 0.040 & $-0.004 * *$ \\
\hline Loans / assets & 0.664 & 0.637 & $0.027 * * *$ & 0.684 & 0.651 & $0.033 * * *$ \\
\hline Derivatives (trading) / assets & 0.078 & 0.004 & $0.074 * * *$ & 0.000 & 0.000 & $0.000 * * *$ \\
\hline Derivatives (other) / assets & 0.025 & 0.006 & $0.019 * * *$ & 0.005 & 0.000 & $0.005 * * *$ \\
\hline \multicolumn{7}{|l|}{$\begin{array}{l}\text { Repurchases, Growth, and } \\
\text { Taxes }\end{array}$} \\
\hline Repurchase indicator variable & 0.524 & 0.468 & $0.056 * * *$ & 0.545 & 0.500 & 0.045 \\
\hline Asset growth excluding mergers & 0.122 & 0.092 & $0.030 * * *$ & 0.108 & 0.071 & $0.037 * * *$ \\
\hline Number of mergers in a year & 0.388 & 0.221 & $0.167 * * *$ & 0.188 & 0.000 & $0.188 * * *$ \\
\hline State tax rate & 0.069 & 0.073 & $-0.004 * *$ & 0.070 & 0.077 & $-0.007 * * *$ \\
\hline
\end{tabular}




\section{Table 3: Determinants of Initial TPS Issuance}

The table reports results from a Cox proportional hazard model. The sample consists of 6,512 bank holding company-years, which track 857 unique BHCs. The time variable is years in sample until first issuance of TPS (the event) or until the BHC quits the sample. The status or event variable is first-time issuance of TPS. Of the 857 BHCs, 518 issue TPS during our sample (experience the event); all other BHCs are treated as right-censored in the regressions. The accounting data are taken from year -1 , where year -1 is defined as the fiscal year ending just prior to the date the time variable is measured. We exclude acquired TPS. The table reports exponentiated coefficients (hazard ratios). Coefficients with statistical significance at the $10 \%, 5 \%$, and $1 \%$ level are indicated with ${ }^{*},{ }^{* *}$, and ${ }^{* * *}$ respectively.

\section{Proxies for capital constraints}

Franchise value $_{\mathrm{t}-1}$

Tier 1 ratio $_{\mathrm{t}-1}(\%)$

\section{(1)}

$0.157^{*}$
(2)

$0.077^{* * *}$

$1.312^{* * *}$

$5.990^{* * *}$

$2.439^{* *}$

$0.886^{* * *}$

$2.418^{* * *}$

0.943

0.990

$0.458^{* * *}$

$2.925^{* *}$

$0.001^{* * *}$

1.049

$2.124^{* * *}$

1.125
$1.300^{* * *}$

$4.384^{* * *}$

$2.664^{* * *}$

$0.898^{* * *}$

$2.347^{* * *}$

0.871

1.050

$0.471^{* * *}$

$2.828^{* *}$

$0.001^{* * *}$

0.965

$2.168^{* * *}$

1.130
$1.097^{*}$

0.972

$1.966^{*}$

$0.907^{* * *}$

$2.252^{* * *}$

1.017

0.943

$0.479^{* *}$

0.783

$0.003^{* * *}$

0.799

$1.911^{* * *}$

0.848
(4)

(5)

Derivatives (other) / assets $_{-t-1}$

Repurchases, growth, and taxes

Repurchase dummy variable

Asset growth excluding mergers

$1.241^{* *}$

$3.387^{* * *}$

$1.154^{* * *}$

Number of mergers $\mathrm{t}_{\mathrm{t}}$

8.862

1.044

1.088

0.628

0.629

$2.154^{* *}$

1.878

$0.916^{* * *}$

$2.086^{* * *}$

0.948

$2.430^{* * *}$

0.950

1.007

$0.505^{* *}$

1.010

1.009

$0.512^{* *}$

0.696

$0.003^{* * *}$

0.990

$0.006^{* * *}$

0.602

$1.952^{* * *}$

0.634

1.159

$1.858^{* * *}$

1.017

State tax rate t-1 $_{1}$

$\begin{array}{ll}1.408^{* * *} & 1.387^{* * *} \\ 4.544^{* * *} & 4.942^{* * *} \\ 1.123^{* * *} & 1.124^{* * *} \\ 1.858 & 2.178\end{array}$

\begin{tabular}{lccccc}
\hline $\mathrm{N}$ & 3,238 & 3,238 & 3,238 & 3,238 & 3,238 \\
Includes year-fixed effects? & Yes & Yes & Yes & Yes & Yes \\
\hline
\end{tabular}




\section{Table 4: TPS Level and Bank Characteristics}

The table presents results from regressions of TPS / Tier 1 capital on bank characteristics. The sample consists of 6,512 bank-holding company-years (BHC-years). Independent variables are lagged one period, and described in detail in Section 3. Regressions in Columns (1) to (4) include year-fixed effects and BHC-fixed effects, with standard errors clustered by BHC. Regressions in Columns (5) to (7) do not include BHC-fixed effects but take into account that the dependent variable is left-censored at zero. Column (6) also right-censors the dependent variable at 0.25 . Standard errors are clustered by BHC and year. Column (7) reports a regression in which the Tier 1 ratio and franchise value are lagged by 5 years. The number of observations is lower because Tier 1 capital is not reported in our data source prior to 1995. Coefficients with statistical significance at the $10 \%, 5 \%$, and $1 \%$ level are indicated with ${ }^{*}{ }^{* *}$, and ${ }^{* * *}$ respectively, and p-values are reported below the coefficients in parentheses.

\section{Proxies for capital constraints \\ Franchise value $_{\mathrm{t}-1}$}

Tier 1 ratio $_{\mathrm{t}-1}(\%)$

Franchise value $_{\mathrm{t}-5}$

Tier 1 ratio $_{\mathrm{t}-5}$

Bank Characteristics

Internationally active indicator variable

Log total assets $\mathrm{s}_{\mathrm{t}-1}$

Risk-weighted assets / total assets $_{\mathrm{t}-1}$

\begin{tabular}{cc}
\hline & \multicolumn{2}{c}{ Fixed Ef } \\
\hline$(1)$ & $(2)$ \\
\hline & \\
$-0.091^{*}$ & $-0.107^{* *}$ \\
$(0.06)$ & $(0.03)$
\end{tabular}

Insider ownership $\mathrm{t}_{-1}$

Return on assets $\mathrm{t}_{\mathrm{t}-1}(\%)$

Stock return $_{\mathrm{t}-1}$

Beta $_{\mathrm{t}-1}$

Idiosyncratic volatility $_{\mathrm{t}-1}(\%)$

Loan concentration index $\mathrm{x}_{\mathrm{t}-1}$

Deposits / assets $_{\mathrm{t}-1}$

Cash / assets $_{\mathrm{t}-1}$

Loans / assets $_{\mathrm{t}-1}$

Derivatives (trading) / assets t-1

Derivatives (other) / assets t-1

Growth, mergers, taxes

Repurchase dummy ${ }_{t}$

Asset growth excluding mergers $\mathrm{t}_{\mathrm{t}}$

Number of mergers $t_{t}$

State tax rate $_{\mathrm{t}-1}$

$$
\begin{gathered}
0.028^{* * *} \\
(0.00) \\
0.156^{* * *} \\
(0.00) \\
0.068^{* *} \\
(0.04)
\end{gathered}
$$

$-0.004^{* * *}$

(0.00)

$0.013^{* * *}$

$-0.001$

(0.89)

$0.003^{*}$

(0.08)

0.046

(0.12)

$-0.120^{* * * *}$

(0.00)

$-0.065$

(0.32)

$-0.094^{* *}$

(0.02)

$-0.047^{* * * *}$

$(0.01)$

(0.00)

\begin{tabular}{lcc} 
& $-0.008^{* *}$ & $-0.007^{* *}$ \\
& $(0.02)$ & $(0.04)$ \\
& $0.046^{* *}$ & $0.046^{* * *}$ \\
& $(0.00)$ & $(0.00)$ \\
& 0.002 & 0.001 \\
& $(0.38)$ & $(0.62)$ \\
& 0.208 & 0.225 \\
& $(0.54)$ & $(0.51)$ \\
\hline 6,512 & 6,512 & 6,512 \\
Yes & Yes & Yes \\
Yes & Yes & Yes \\
0.20 & 0.20 & 0.21 \\
\hline & &
\end{tabular}

0.20

$(3)$

$-0.002^{* * *}$
$(0.01)$

$(4)$
$-0.118^{* *}$
$(0.02)$
$-0.002^{* * *}$
$(0.01)$

(0.01)

$0.039^{* * *}$

$(0.00)$
$0.141^{* * *}$

$$
\text { (0.00) }
$$

0.063

(0.06)

$-0.004^{* * *}$

(0.00)$$
\text { (0.02) }
$$

$$
-0.001
$$

$0.004^{* *}$

(0.04)

$$
0.045
$$

(0.13)

$-0.116^{* * *}$

(0.00)

$$
-0.061
$$

(0.36)

$-0.091^{* *}$

(0.02)

$-0.047^{* * *}$

$(0.01)$
$-0.116^{* * *}$

(0.00)

$0.036^{* * *}$

$(0.00)$
$0.111^{* * *}$

(0.01)

0.052

(0.112

$-0.004^{* * *}$

(0.00)

0.006

(0.15)

$-0.001$

$0.90)$

$0.004^{* *}$

(0.05)

0.046

(0.12)

$-0.129^{* * *}$

(0.00)

$-0.072$

(0.28)

$-0.093^{* *}$

(0.02)

$-0.040^{* *}$

(0.03)

$-0.100^{* *}$

(0.02)

0.21

$0.037^{* * *}$
$(0.00)$
$0.113^{* * *}$
$(0.01)$

0.054

(0.11)

$-0.003^{* * *}$

(0.00)

$0.012^{* *}$

(0.02)

0.000

(0.98)

$0.004^{* *}$

(0.05)

0.048

(0.11)

$-0.125^{* * *}$

$-0.064$

(0.34)

$-0.096^{* * *}$

(0.01)

$-0.043^{* *}$

(0.02)

$-0.109^{* * *}$

(0.01)

$-0.007^{* *}$

(0.04)

$0.048^{\text {*** }}$

(0.00)

0.002

(0.36)

0.201

(0.55)

6,512

6,512
Yes

No

0.23
Tobit

(6)

(6)

$\begin{array}{cc}-0.392^{* * *} & -0.436^{* * *} \\ (0.00) & (0.00) \\ -0.014^{* * *} & -0.015^{* * *} \\ (0.00) & (0.00)\end{array}$

$-0.200^{* *}$

(0.02)

$-0.013^{* * *}$

(0.00)

(0.13)

$0.014^{* * *}$

$-0.114$

$-0.041^{* * *}$

(0.01)

0.102

(0.18)

$0.119^{* * * *}$

(0.01)

$-0.009^{* * * *}$

(0.00)

$0.046^{* * *}$

(0.00)

$0.016^{* *}$

(0.05)

0.235

(0.55)

$-0.050$

(0.17)

$-0.095$

(0.12)

$-0.301^{*}$

(0.06)

$-0.155^{* *}$

(0.03)

0.026

(0.50)

$-0.131^{* * *}$

(0.04)

(0.14)

(0.54)

$0.017^{* * *}$

0.001

(0.01)

(0.85)

0.122

(0.15)

$0.133^{* *}$

0.023

(0.75)

(0.01)

$-0.010^{* * *}$

(0.00)

0.094

(0.06)

$-0.012^{* * *}$

$(0.00)$
$0.017^{* *}$

(0.00) (0.05)

$0.018^{* * *}$

0.013

(0.05)

(0.11)

0.318

0.004

(0.46)

$-0.047$

(0.24)

(0.30)

$-0.099$

$-0.022$

(0.54)

(0.14) (0.22)

$-0.318^{*}$

$-0.342^{* *}$

(0.07)

(0.02)

$-0.159^{* *} \quad-0.031$

(0.04) (0.68)

0.026

$-0.003$

(0.55)

$-0.148^{* *}$

(0.94)

(0.04)

$-0.029$

(0.63)

$\begin{array}{lll}-0.005 & -0.005 & -0.017^{* *}\end{array}$

$(0.50)$

$0.122^{* * *}$

$(0.56)$

$0.129^{* * *}$

(0.02)

(0.00)

$0.012^{* * * *}$

$(0.00) \quad(0.00)$

(0.00)

0.013

$0.017^{* * *}$

(0.00) (0.00)

(0.10)

0.341

0.148

6,512

(0.11)

(0.43)

Includes year-fixed effects?

$\mathrm{R}^{2}$ 


\section{Table 5: ABCP Conduits and Trust Preferred Securities}

The table presents results from regressions of ABCP conduit total exposure, credit exposure and liquidity exposure scaled by risk-weighted assets, on bank characteristics. Since these data are only available since 2001, the sample consists of 3,996 bank holding company-years (BHC-years). Independent variables are lagged one period, and described in detail in Sections 3 and 4. Regressions in Columns (1) to (3) include year-fixed effects and BHC-fixed effects, with standard errors clustered by BHC. Regressions in Columns (4) to (6) do not include BHC-fixed effects but take into account that the dependent variable is left-censored at zero. Coefficients with statistical significance at the $10 \%, 5 \%$, and $1 \%$ level are indicated with ${ }^{*},{ }^{* * *}$, and ${ }^{* * *}$ respectively, and p-values are reported below the coefficients in parentheses.

Dependent Variable:

ABCP/Risk-weighted assets

\section{Proxies for capital constraints}

Franchise value $_{t-1}$

Tier 1 ratio $_{\mathrm{t}-1}$

\section{Bank Characteristics}

Log total assets ${ }_{\mathrm{t}-1}$

Short-term debt / assets $_{\mathrm{t}-1}$

Loans / assets $\mathrm{t}_{-1}$

Deposits / assets $_{\mathrm{t}-1}$

\begin{tabular}{|c|c|c|c|c|c|}
\hline \multicolumn{3}{|c|}{ Fixed-effects } & \multicolumn{3}{|c|}{ Tobits } \\
\hline Total & Credit & Liquidity & Total & Credit & Liquidity \\
\hline $\mathrm{ABCP}$ & $\mathrm{ABCP}$ & ABCP & ABCP & ABCP & ABCP \\
\hline$(1)$ & $(2)$ & (3) & (4) & (5) & $(6)$ \\
\hline 0.005 & 0.001 & 0.003 & 0.032 & 0.007 & -0.005 \\
\hline$(0.27)$ & $(0.16)$ & $(0.48)$ & $(0.65)$ & $(0.34)$ & (0.95) \\
\hline$-0.017^{* * *}$ & $-0.001^{*}$ & $-0.014^{* * *}$ & $-0.615^{* * *}$ & $-0.047^{*}$ & $-0.724^{* * *}$ \\
\hline$(0.01)$ & $(0.07)$ & $(0.01)$ & $(0.01)$ & $(0.08)$ & $(0.00)$ \\
\hline $0.002^{* * *}$ & $0.000^{* * *}$ & $0.002^{* * *}$ & $0.032^{* * *}$ & $0.003^{* * *}$ & $0.034^{* * *}$ \\
\hline$(0.00)$ & $(0.00)$ & $(0.00)$ & $(0.00)$ & $(0.00)$ & $(0.00)$ \\
\hline 0.006 & 0.000 & 0.006 & 0.104 & 0.010 & 0.140 \\
\hline$(0.36)$ & (0.52) & (0.33) & $(0.34)$ & $(0.34)$ & $(0.20)$ \\
\hline-0.002 & 0.000 & -0.002 & -0.067 & -0.005 & $-0.094^{* * *}$ \\
\hline$(0.32)$ & $(0.83)$ & $(0.24)$ & $(0.07)$ & $(0.32)$ & $(0.01)$ \\
\hline 0.002 & 0.000 & 0.002 & 0.099 & 0.010 & $0.151^{* *}$ \\
\hline$(0.59)$ & $(0.61)$ & $(0.47)$ & $(0.15)$ & $(0.16)$ & $(0.04)$ \\
\hline 3,996 & 3,996 & 3,996 & 3,996 & 3,996 & 3,996 \\
\hline Yes & Yes & Yes & Yes & Yes & Yes \\
\hline Yes & Yes & Yes & No & No & No \\
\hline 0.02 & 0.01 & 0.02 & & & \\
\hline
\end{tabular}




\section{Table 6: Distance to Default and TPS Usage}

The table presents results from pooled time-series cross-sectional OLS regressions of the z-score on TPS usage and other bank characteristics. The z-score is calculated as (ROA + capital ratio) /sigma(ROA)]. ROA is calculated as the sum of quarterly net income over one year divided by end-of-year total assets. The capital ratio (market value of equity / total assets) in the numerator is calculated as end-of-year. Sigma ROA is calculated using quarterly data from the six years prior to the year of interest. Independent variables are lagged one period, and described in detail in Sections 3 and 4. In Columns (1) and (2), the dependent variable is the raw z-score. In Columns (3) and (4), the dependent variable is the log of the $z$-score. The $z$-score is winsorized at the $1 \%$ and $99 \%$ tails. The independent variables are described in Sections 3 and 4. Regressions include year-fixed effects. Standard errors are clustered by bank and by year. Coefficients with statistical significance at the $10 \%, 5 \%$, and $1 \%$ level are indicated with ${ }^{*},{ }^{* *}$, and ${ }^{* * *}$ respectively, and p-values are reported below the coefficients in parentheses.

\begin{tabular}{|c|c|c|c|c|}
\hline & \multicolumn{2}{|c|}{ Continuous z-score } & \multicolumn{2}{|c|}{ Log z-score } \\
\hline & $(1)$ & $(2)$ & (3) & (4) \\
\hline TPS / Tier $1_{\mathrm{t}-1}$ & $\begin{array}{c}-7.072^{* *} \\
(0.02)\end{array}$ & $\begin{array}{c}-4.029^{* *} \\
(0.02)\end{array}$ & $\begin{array}{c}-0.668^{* * *} \\
(0.01)\end{array}$ & $\begin{array}{c}-0.352^{* * *} \\
(0.00)\end{array}$ \\
\hline Tier 1 ratio $_{\mathrm{t}-1}$ & & $\begin{array}{c}0.173^{* * *} \\
(0.01)\end{array}$ & & $\begin{array}{c}0.013^{* * *} \\
(0.01)\end{array}$ \\
\hline Stock return ${ }_{\mathrm{t}-1}$ & & $\begin{array}{c}4.587^{* * *} \\
(0.00)\end{array}$ & & $\begin{array}{c}0.309^{* * *} \\
(0.00)\end{array}$ \\
\hline Log (market value) $)_{t-1}$ & & $\begin{array}{l}0.271 \\
(0.32)\end{array}$ & & $\begin{array}{l}-0.008 \\
(0.63)\end{array}$ \\
\hline Beta $_{t-1}$ & & $\begin{array}{r}-0.497 \\
(0.40)\end{array}$ & & $\begin{array}{c}-0.023 \\
(0.66)\end{array}$ \\
\hline Idiosyncratic volatility $_{\mathrm{t}-1}$ & & $\begin{array}{c}-0.801^{* * *} \\
(0.01)\end{array}$ & & $\begin{array}{c}-0.126^{* * *} \\
(0.00)\end{array}$ \\
\hline Book / market $_{\mathrm{t}-1}$ & & $\begin{array}{c}-3.285^{* * *} \\
(0.00)\end{array}$ & & $\begin{array}{c}-0.462^{* * *} \\
(0.00)\end{array}$ \\
\hline Loan concentration index $\mathrm{t}_{\mathrm{t}-1}$ & & $\begin{array}{c}-4.470^{* * *} \\
(0.00)\end{array}$ & & $\begin{array}{c}-0.348^{* * *} \\
(0.00)\end{array}$ \\
\hline Mean asset growth, past 3 years & & $\begin{array}{c}4.623^{* *} \\
(0.02)\end{array}$ & & $\begin{array}{c}0.373^{* * *} \\
(0.00)\end{array}$ \\
\hline Constant & $\begin{array}{c}12.368^{* * *} \\
(0.00)\end{array}$ & $\begin{array}{c}16.724^{* * *} \\
(0.00)\end{array}$ & $\begin{array}{c}2.294^{* * *} \\
(0.00)\end{array}$ & $\begin{array}{c}3.417^{* * *} \\
(0.00)\end{array}$ \\
\hline $\mathrm{N}$ & 6,095 & 5,340 & 5,876 & 5,140 \\
\hline Includes year-fixed effects? & Yes & Yes & Yes & Yes \\
\hline $\mathrm{R}^{2}$ & 0.37 & 0.54 & 0.33 & 0.55 \\
\hline
\end{tabular}




\section{Table 7: CPP and TPS Usage}

The table shows results from probit regressions in which the dependent variable is set to 1 if the firm ever received funds from the Capital Purchase Program (CPP) of the Troubled Asset Relief Program (TARP), and 0 otherwise. The independent variables are measured pre-crisis in June 2007 and are described in Sections 3 and 4. The six banks in our sample that were required to take CPP funds (listed in Section 5.E.2) are omitted from the analysis. The table reports marginal effects. Coefficients with statistical significance at the $10 \%, 5 \%$, and $1 \%$ level are indicated with ${ }^{*},{ }^{* *}$, and ${ }^{* * *}$ respectively, and p-values from heteroskedasticity-adjusted standard errors are reported below the coefficients in parentheses.

\section{TPS / Tier 1}

Tier 1 ratio

Leverage ratio

Return on assets before taxes $7 / 2006$ to $6 / 2007$

Stock return $7 / 2006$ to $6 / 2007$

Log (total assets)

Beta

Idiosyncratic volatility

Book / market

Loan concentration index

Mean asset growth ratio, past 3 years

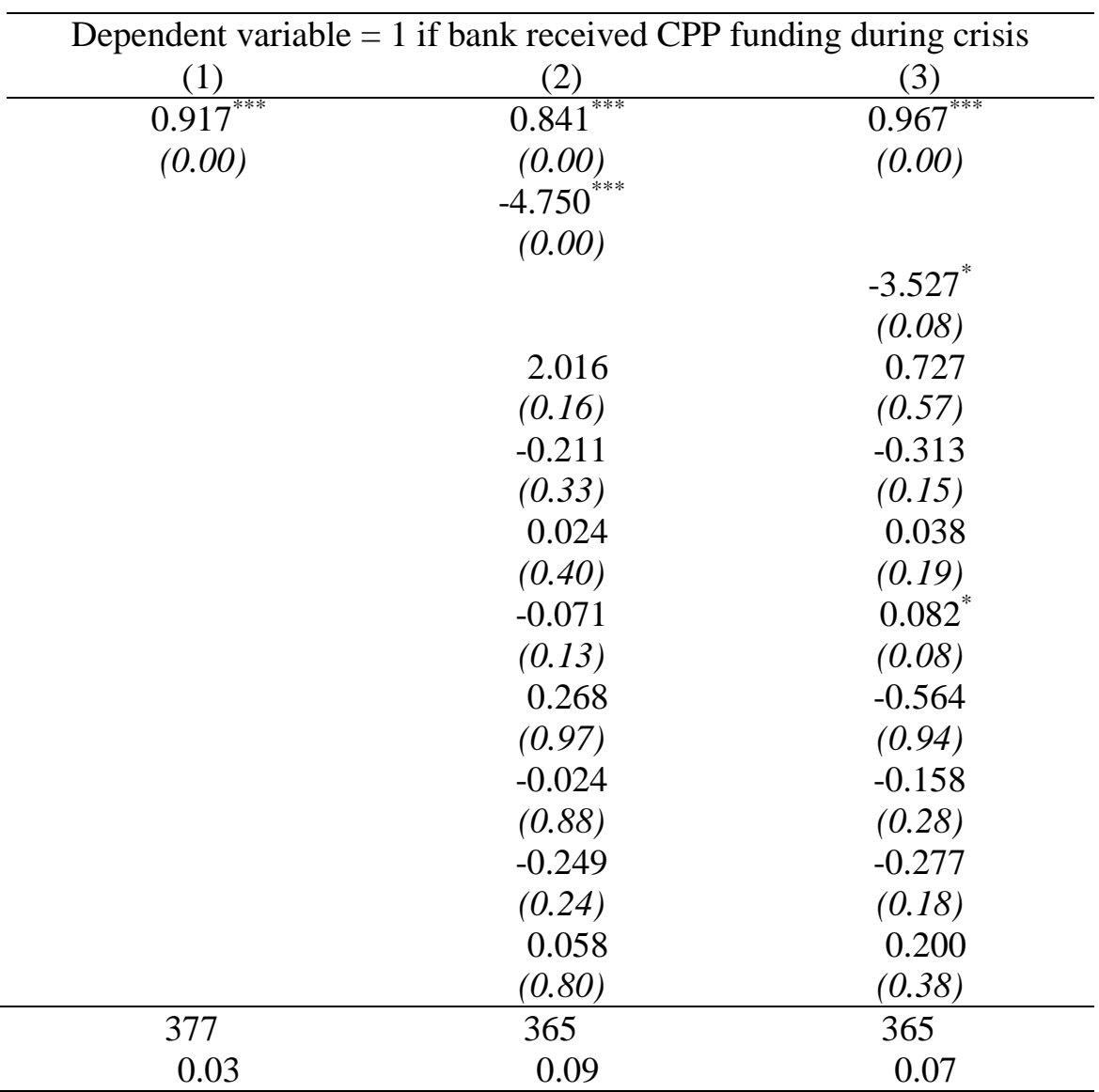




\section{Table 8: Crisis Returns and TPS Usage}

The table shows results from cross-sectional regressions of crisis returns on bank characteristics, measured in June 2007. In Columns (1)-(3) the dependent variable is the buy-and-hold stock return of bank holding companies, and in Columns (4)-(6), the dependent variable is the return on assets before income tax. Returns are calculated from July 2007 through December 2008. The independent variables are described in Sections 3 and 4. Coefficients with statistical significance at the $10 \%, 5 \%$, and $1 \%$ level are indicated with ${ }^{*},{ }^{* *}$, and ${ }^{* * *}$ respectively, and p-values from heteroskedasticity-adjusted standard errors are reported below the coefficients in parentheses.

\begin{tabular}{|c|c|c|c|c|c|c|}
\hline & \multicolumn{3}{|c|}{ Stock market return } & \multicolumn{3}{|c|}{ Return on assets before income tax } \\
\hline & (1) & $(2)$ & (3) & (4) & (5) & $(6)$ \\
\hline TPS / Tier 1 & $-0.320^{* * *}$ & -0.163 & $-0.272^{* *}$ & $-0.065^{* * *}$ & $-0.028^{* *}$ & $-0.031^{* *}$ \\
\hline Tier 1 ratio & $(0.01)$ & $\begin{array}{c}(0.17) \\
1.587^{* * *} \\
(0.00)\end{array}$ & $(0.02)$ & $(0.00)$ & $\begin{array}{r}(0.05) \\
0.028 \\
(0.67)\end{array}$ & $(0.03)$ \\
\hline Regulatory leverage ratio & & & $\begin{array}{l}-0.741 \\
(0.29)\end{array}$ & & & $\begin{array}{l}-0.178 \\
(0.11)\end{array}$ \\
\hline $\begin{array}{l}\text { Return on assets before taxes } \\
7 / 2006 \text { to } 6 / 2007\end{array}$ & & & & & $\begin{array}{r}0.152 \\
(0.11)\end{array}$ & $\begin{array}{l}0.219^{* *} \\
(0.04)\end{array}$ \\
\hline Log (total assets) & & & & & $\begin{array}{c}-0.002^{*} \\
(0.10)\end{array}$ & $\begin{array}{c}-0.003^{* * *} \\
(0.01)\end{array}$ \\
\hline Stock return $7 / 2006$ to $6 / 2007$ & & $\begin{array}{r}-0.029 \\
(0.77)\end{array}$ & $\begin{array}{r}0.056 \\
(0.56)\end{array}$ & & & \\
\hline Log (market value) & & $\begin{array}{c}-0.039^{* * *} \\
(0.00)\end{array}$ & $\begin{array}{c}-0.046^{* * *} \\
(0.00)\end{array}$ & & & \\
\hline Beta & & $\begin{array}{c}0.086^{* * *} \\
(0.00)\end{array}$ & $\begin{array}{l}0.092^{* * *} \\
(0.00)\end{array}$ & & $\begin{array}{l}-0.001 \\
(0.58)\end{array}$ & $\begin{array}{l}-0.001 \\
(0.65)\end{array}$ \\
\hline Idiosyncratic volatility & & $\begin{array}{c}-11.281^{* * *} \\
(0.00)\end{array}$ & $\begin{array}{l}-11.080^{* * *} \\
(0.00)\end{array}$ & & $\begin{array}{r}-0.021 \\
(0.95)\end{array}$ & $\begin{array}{l}-0.023 \\
(0.95)\end{array}$ \\
\hline Book/market & & $\begin{array}{c}-0.153^{* * *} \\
(0.01)\end{array}$ & $\begin{array}{c}-0.135^{* *} \\
(0.03)\end{array}$ & & $\begin{array}{c}-0.048^{* * *} \\
(0.00)\end{array}$ & $\begin{array}{c}-0.046^{* * *} \\
(0.00)\end{array}$ \\
\hline Loan concentration index & & $\begin{array}{c}-0.358^{* * *} \\
(0.00)\end{array}$ & $\begin{array}{l}-0.296^{* * *} \\
(0.00)\end{array}$ & & $\begin{array}{c}-0.030^{* * *} \\
(0.00)\end{array}$ & $\begin{array}{c}-0.028^{* * *} \\
(0.00)\end{array}$ \\
\hline $\begin{array}{l}\text { Mean asset growth, past } 3 \\
\text { years }\end{array}$ & & $\begin{array}{c}-0.317^{* * *} \\
(0.00)\end{array}$ & $\begin{array}{c}-0.374^{* * *} \\
(0.00)\end{array}$ & & $\begin{array}{l}-0.049^{* * *} \\
(0.00)\end{array}$ & $\begin{array}{c}-0.050^{* * *} \\
(0.00)\end{array}$ \\
\hline Constant & $\begin{array}{c}-0.203^{* * *} \\
(0.00) \\
\end{array}$ & $\begin{array}{c}0.543^{* * *} \\
(0.01) \\
\end{array}$ & $\begin{array}{l}0.858^{* * *} \\
(0.00)\end{array}$ & $\begin{array}{l}0.019^{* * *} \\
(0.00)\end{array}$ & $\begin{array}{l}0.092^{* * *} \\
(0.00)\end{array}$ & $\begin{array}{l}0.122^{* * *} \\
(0.00)\end{array}$ \\
\hline Observations & 382 & 370 & 370 & 377 & 365 & 365 \\
\hline $\mathrm{R}^{2}$ & 0.02 & 0.23 & 0.20 & 0.05 & 0.29 & 0.30 \\
\hline
\end{tabular}

